\title{
Ailadinium reticulatum gen. et sp. nov. (Dinophyceae), a New Thecate, Marine, Sand-Dwelling Dinoflagellate from the Northern Red Sea
}

\author{
Saburova Maria ${ }^{1,{ }^{*}}$, Chomérat Nicolas ${ }^{2}$ \\ ${ }^{1}$ Inst Biol Southern Seas, UA-99011 Sevastopol, Ukraine. \\ 2 IFREMER, Stn Biol Marine, LER BO, F-29900 Concarneau, France. \\ *Corresponding author : Maria Saburova, email address : msaburova@gmail.com
}

\begin{abstract}
:
A new photosynthetic, sand-dwelling marine dinoflagellate, Ailadinium reticulatum gen. et sp. nov., is described from the Jordanian coast in the Gulf of Aqaba, northern Red Sea, based on detailed morphological and molecular data. A. reticulatum is a large (53-61 $\mu \mathrm{m}$ long and 38-48 $\mu \mathrm{m}$ wide), dorsoventrally compressed species, with the epitheca smaller than the hypotheca. The theca of this new species is thick and peculiarly ornamented with round to polygonal depressions forming a foveatereticulate thecal surface structure. The Kofoidian thecal tabulation is APC (Po, cp), 4', 2a, 6", 6c, 4s, 6"', $1 \mathrm{p}, 1^{\prime \prime \prime \prime}$ or alternatively it can be interpreted as APC, 4', 2a, 6", 6c, 4s, 6"', $2^{\prime \prime \prime \prime}$. The plate pattern of $A$. reticulatum is noticeably different from described dinoflagellate genera. Phylogenetic analyses based on the SSU and LSU rDNA genes did not show any supported affinities with currently known thecate dinoflagellates.
\end{abstract}

Keywords: benthic dinoflagellates, Dinophyceae, Gulf of Aqaba, Jordan, LSU rDNA, molecular phylogeny, morphology, Red Sea, SSU rDNA, taxonomy 
In recent decades, it has been shown that marine bottom sediments are inhabited by diverse and abundant assemblage of dinoflagellates (e.g. Balech 1956; Fukuyo 1981; Larsen 1985; Hoppenrath 2000a; Faust et al. 2005; Murray 2009; Saburova et al. 2009). Among them, many new taxa with unusual plate patterns have been found and described (e.g. Nie and Wang 1944; Faust and Balech 1993; Horiguchi 1995; Murray and Patterson 2004; Hoppenrath and Selina 2006; Murray et al. 2006; Chomérat and Nézan 2009; Chomérat et al. 2010a; Nézan and Chomérat 2011), but benthic dinoflagellates remain still poorly investigated compared to planktonic species.

The relatively short Jordanian coast of the northern Red Sea (the Gulf of Aqaba) is known for its well-developed inshore coral reefs that provide a perfect habitat for biota and support abundant and diverse communities of coral fish and benthic invertebrates (UNEP/IUCN 1988). Studies of this marine ecosystem have been focused more on macrobenthic communities (e.g. Ismail 1986; Al-Zibdah et al. 2007), while yet little information exists on microbenthic organisms, despite their probable importance in supplying the next trophic levels. Very recently, benthic dinoflagellate assemblages have been preliminarily described for the first time with emphasis on ciguatera-related species for the central Red Sea off the Saudi Arabia coast (Catania 2012), and from the northern Red Sea (Saburova et al. 2013); however, there is considerable diversity yet to be described in sand-dwelling dinoflagellates of this region.

During preliminary taxonomic surveys of the benthic dinoflagellates inhabiting the bottom sandy sediments within inshore coral reef at Jordanian coast in the northern Red Sea, we have recorded a large-sized photosynthetic sand-dwelling dinoflagellate with unique features that cannot be associated with any currently described species or genus. The present paper describes this taxon on the basis of light and electron microscopical observations and phylogenetic rDNA study. 
Sampling

63

64

65

66

67

68

69

Samples were collected at Jordanian coast in the northern Red Sea in the Gulf of Aqaba along the Aqaba Marine Park zone. The Jordanian coastline has a length of about $27 \mathrm{~km}$ with a discontinuous series of fringing reefs of $13 \mathrm{~km}$ length, interrupted by bays, which are mostly covered with seagrass meadows (UNEP/IUCN 1988). The average monthly seawater temperature of the Gulf of Aqaba ranges from $21^{\circ} \mathrm{C}$ during February-March to about $26^{\circ} \mathrm{C}$ in August-September with the seasonal amplitude of about $5.5^{\circ} \mathrm{C}$. The average value of salinity is close to 40.6 (Al-Rousan et al. 2007).

During the course of sampling in the Aqaba Marine Park at $29^{\circ} 25^{\prime} 58^{\prime \prime} \mathrm{N}, 34^{\circ} 58^{\prime 2} 26^{\prime \prime} \mathrm{E}$, a total of 22 samples of the bottom sediments were collected on 24 October 2009, 29 and 30 October 2010, and 30 October 2011. Samples were collected on the shallow slope of the inshore fringing coral reef, where carbonate sands dominated, at depths of 1.5-3 m during snorkeling. The upper layer of the sand was scraped to a depth $0.5-1 \mathrm{~cm}$ using $50 \mathrm{ml}$ Falcon tubes by diver. The water temperatures ranged between $23-25^{\circ} \mathrm{C}$ during sampling courses.

\section{Sample processing}

The sand-dwelling dinoflagellate cells were separated from the sandy sediment by extraction using the frozen seawater method (Uhlig 1964) with a $110 \mu \mathrm{m}$ mesh size. The material was preliminary viewed alive with a Leica DMIL inverted microscope at $35 \times$ to $200 \times$ magnifications. Alternatively, one replicate of each sample was preserved by 4\% Lugol's solution and utilized to examine by SEM or molecular analysis.

Cells of Ailadinium reticulatum were rarely observed, being found on just two sampling occasions in 2009 and 2011, and in one occasion only in 2010. Despite diligent searching in all collected samples, only 31 specimens were found and were available to us for both 
morphological and molecular analysis. For this reason, culture studies of this species have not been carried out.

\section{Light and scanning electron microscopy}

For detailed observation, cells were isolated by micropipetting in preparation for highmagnification photomicroscopy, and were examined with the Leica DMLM (Leica, Wetzlar, Germany) microscope at $630 \times$ to $1000 \times$ magnification. LM observation of the thecal plate tabulation was performed on cells stained with Calcofluor White M2R (Sigma Chemical Co.) according to the method of Fritz and Triemer (1985). To visualize nuclei, 4',6-diamidino-2phenylindole (DAPI) fluorochrome was applied to cells fixed in $2.5 \%$ glutaraldehyde.

Micrographs were obtained using Leica DMLM microscope equipped with epifluorescence (100 W short arc mercury lamp), DIC optics, and Leica DFC 320 digital camera.

SEM was employed for detailed observations of the thecal surface. For SEM, cells were individually isolated and concentrated in $0.2 \mathrm{~mL}$ tubes containing distilled water and a drop of formaldehyde to prevent fungal development. Cells were filtered using polycarbonate membrane filters (Millipore RTTP Isopore, $1.2 \mu \mathrm{m}$ pore size, Millipore, Billerica, MA, USA), rinsed in deionized water, and prepared according to Chomérat and Couté (2008). The examination was performed using a Quanta 200 (FEI, Eindhoven, the Netherlands) scanning electron microscope with an electron acceleration of $5 \mathrm{kV}$. The SEM photographs were presented on a uniform background using Adobe Photoshop CS2, v. 9.0.2 (Adobe Systems, San Jose, CA, USA). Morphometric measurements were made either from the calibrated digital LM images using Leica Application Suite v. 3.7 software (Leica Microsystems Ltd, Switzerland) or were calculated from scanning electron micrographs. Cell dimensions were measured in 12 specimens. Dimensions are given as the mean \pm standard deviation. 
113 To describe the thecal plate tabulation, the nomenclature of Kofoid $(1909,1911)$ was applied,

114 and the alternative plate pattern interpretation follows Balech $(1980,1988)$. The nomenclature of

115 Dodge and Hermes (1981) was applied for description of the apical pore complex. The general

116 dinoflagellate classification scheme proposed by Fensome et al. (1993) was adopted.

118 DNA amplification and sequencing

119 Single cells were isolated from samples with a capillary pipette under an Olympus IX41 inverted

120 microscope (Olympus, Tokyo). They were rinsed in several drops of distilled water and then

121 placed in a $0.2 \mathrm{~mL}$ PCR tube containing $5 \mu 1$ of distilled water. Then, the tubes were stored at -

$12220^{\circ} \mathrm{C}$ prior to analysis. For PCR, tubes were thawed and processed as described previously in

123 Chomérat et al. (2010b, 2012).

Phylogenetic analyses

126 The SSU sequences obtained were aligned with other dinoflagellates sequences and other

127 Alveolates as external group, using MAFFT software version 7 (Katoh and Standley 2013) with

128 selection of the Q-INS-i algorithm which considers the secondary structure for the alignment.

129 The alignments were then refined by eye with MEGA software version 5.2.1 (Tamura et al.

130 2011). For SSU a dataset of 77 taxa, including a sequence of Perkinsus marinus as outgroup, and

1311691 aligned positions has been used. For LSU, ambiguous parts of the alignment (including the

132 D2 domain) were excluded from the analysis using Gblocks software version 0.91b (Castresana

133 2000), with less stringent parameters. As a result a matrix of 52 taxa including three Ciliates

134 sequences as outgroups, and 812 positions was used. GenBank accession numbers of all

135 sequences used are available in the supplementary material (Appendix S1).

136 For each data set, evolutionary models were examined using maximum likelihood and

137 Bayesian Inference analysis. The evolutionary model was selected using jModelTest version 
138 0.1.1 (Posada 2008). According to Akaike information criterion (AIC) and Bayesian information

139 criterion (BIC), a general time reversible (GTR) model with a gamma correction $(\Gamma)$ for among-

140 site rate variation and invariant sites was chosen for the SSU dataset while a GTR model with no

141 invariant sites was chosen for the LSU dataset.

142 Maximum likelihood analyses were performed using PhyML version 3.0 (Guindon et al.

143 2010), and Bayesian analyses were run using Mr Bayes version 3.1.2 (Ronquist and Huelsenbeck

144 2003). Bootstrap analysis (1000 pseudoreplicates) was used to assess the relative robustness of

145 branches of the ML tree. Initial Bayesian analyses were run with a GTR model (nst=6) with rates

146 set to invgamma (gamma for LSU dataset). Each analysis was performed using four Markov

147 chains (MCMC), with two millions cycles for each chain. Trees were saved every 100 cycles and

148 the first 2000 trees were discarded. Therefore, a majority-rule consensus tree was created from

149 the remaining 18000 trees in order to examine the posterior probabilities of each clade. The best

150 ML phylograms are shown with robustness values for each node (ML/BI).

152 RESULTS

153 Observations

154 Ailadinium Saburova et Chomérat gen. nov. (Figs. 1-6)

156 Descriptio: Genus repositum in Dinophyta, incertum ordinem et incertam familam; solitarium;

157 marinum; cum theca, photosynthetica et in arena vivens. Thecae laminarum tabulatio APC (Po,

$158 \mathrm{cp}), 4^{\prime}, 2 \mathrm{a}, 66^{\prime \prime}, 6 \mathrm{c}, 4 \mathrm{~s}, 6^{\prime \prime \prime}, 1 \mathrm{p}, 1^{\prime \prime \prime \prime}$. Epitheca deminuta. Cellulae dorsoventraliter compressae.

159 Thecae laminae valde reticulatae.

160

161 Genus of the phylum Dinophyta, order and family uncertain; solitary; marine; with a theca;

162 photosynthetic and sand-dwelling. Plate formula: APC (Po, cp), 4', 2a, 6", 6c, 4s, 6"', 1p, 1'"'. 
163 Epitheca much smaller than hypotheca, cell dorsoventrally compressed. Highly ornamented

164 reticulate theca.

165

166 Etymology: Referring to the ancient Greek name for Aqaba, 'Aila' (Parker 1997), where the

167 dinoflagellate was discovered.

168

169 Type species: Ailadinium reticulatum Saburova et Chomérat sp. nov.

170

171

Ailadinium reticulatum Saburova et Chomérat sp. nov. (Figs. 1-6)

172

173 Descriptio: Generis proprietates. Cellulae ovatae dorsoventraliter complanatae et cum

174 asymetrico hypothecae postico extremo. Longitudo: $53-61 \mu \mathrm{m}$; latitudo: $38-48 \mu \mathrm{m}$; dorsoventralis

175 altitudo 12.5-16.2 $\mu \mathrm{m}$. Epitheca deminuta et leviter minus angusta quam hypotheca. Cingulum supraequatorium et ascendens circa sui latitudine. Sulcus antapicem attingens. Thecae superficies valde reticulata cum circularibus vel polygoniis depressionibus. Chloroplasti lutei-brunnei.

178 Nucleus in hypothecae postica dimidia pars positus.

179

180 Characters as for the genus. Cells ovate, dorsoventrally compressed, with asymmetrically outlined posterior end, 53-61 $\mu \mathrm{m}$ long, 38-48 $\mu \mathrm{m}$ wide, and 12.5-16.2 $\mu \mathrm{m}$ deep. Epitheca slightly narrower and much smaller than hypotheca. Cingulum premedian, ascending, displaced by about a cingular width. Sulcus reaching antapex. Thecal surface strongly ornamented with round to

184 polygonal depressions. Chloroplasts golden-brown. Nucleus in lower half of hyposome.

Habitat: Marine, sand-dwelling. 
189 Dinophyte Taxonomy) dinoflagellate type collection, Wilhelmshaven, Germany.

Type locality: bottom sediments within shallow coral reef in the Aqaba Marine Park $\left(29^{\circ} 25^{\prime} 58^{\prime \prime}\right.$

$\left.\mathrm{N}, 34^{\circ} 58^{\prime 2} 26^{\prime \prime} \mathrm{E}\right)$, the Gulf of Aqaba, northern Red Sea, Jordan.

Etymology: The specific epithet refers to the reticulate structure of the thecal surface, forming polygonal depressions.

The cells are roughly ovate in ventral view and dorsoventrally compressed, with concave ventral side and convex dorsal one (Figs. 1, a-e; 3, a-f). The cells are 53-61 $\mu \mathrm{m}$ long $(55.1 \pm 2.4$, $\mathrm{n}=12), 38-48 \mu \mathrm{m}$ wide $(42.1 \pm 2.9, \mathrm{n}=11)$, and 12.5-16.2 $\mu \mathrm{m}$ deep $(14.9 \pm 2.1, \mathrm{n}=3)$, with a length:width ratio of 1.24-1.39. The epitheca appears cap-shaped, pointed ventrally and rounded dorsally, much smaller and slightly narrower than the hypotheca (Figs. 1, a-f; 2, b, c and d; 3, a, $\mathrm{b}$ and $\mathrm{d} ; 4$, a-d; 6, a and b). The hypotheca is large, almost rectangular, with convex lateral sides (Figs. 1, a-f; 3, a and b; 6, a and b). Cells are irregularly rounded posteriorly, with strongly asymmetrical notched posterior part of the left lateral side (Fig. 1, a-c; 6, a and b). A single, small, claw-shaped antapical spine is located asymmetrically at the right side of the cell (Figs. 1a; 3 , a and $\mathrm{b} ; 5 \mathrm{~g})$. The cingulum is deeply incised, about 3.2-3.5 $\mu \mathrm{m}$ wide. It is slightly ascending with a displacement of about its own width on the ventral side, and horizontal on the dorsal side of the cell (Figs. 1, a-e; 2, a and b; 3, a-d; 4, a-d; 6, a and b). The sulcus extends from the cingulum to the antapex and is wider posteriorly (Figs. 1, a and e; 2, a and g; 3, a, d and e; 5a;

210 6a). The nucleus is spherical and located in the posterior part of the cell just below the middle of

211 hypotheca (Fig. 1, g-i). Thecal plates are thick and remarkably reticulated, which is clearly

212 visible under light microscope (Fig. 1, e and f). The cells contain deeply lobed golden-brown

213 chloroplasts (Fig. 1, a-d and j). There are four peripheral pyrenoids with a ring-like starch 
214 sheaths located at the corners of the hypotheca (Fig. 1, d, e and g). The cytoplasm may also

215 contain one or several large pusules and numerous colorless or colored small globules (Fig. 1, a-

216 d). The transverse flagellum runs inside the cingulum completely around the cell (Fig. 1b). The

217 longitudinal flagellum arises at the upper part of the sulcus, and is slightly longer than the cell

218 length.

The Kofoidian plate formula is APC (Po, cp), 4', 2a, 6", 6c, 4s, 6"', 1p, 1"'". The epitheca consists of 14 plates, comprising two plates of the apical pore complex (Po, cp), four apical plates $\left(1^{\prime}-4^{\prime}\right)$, two anterior intercalary plates $(1 \mathrm{a}, 2 \mathrm{a})$ and six precingular plates $\left(1^{\prime \prime}-6^{\prime \prime}\right)($ Fig. 2 , c$\mathrm{f} ; 4 ; 6$, a-c). The APC is formed by apical pore and cover plates and placed deeper with respect to the plates surrounding it (Figs. 2, c-f; 3d; 4). The outer apical pore plate (Po) is narrow, about 7.3-8.1 $\mu \mathrm{m}$ long, and dorsoventrally oriented. It is hook-shaped and bent toward the left side of the cell (Figs. 3d; 4, b, c and e; 6c). Alongside the inner border of the Po, there is a single row of rectangular depressions surrounding the cover plate (Fig. 4, d and e). The inner cover plate (cp) appears as a long, narrow and hook-shaped ridge that runs through the whole pore plate (Fig. 4, b, c and e; 6c). Its short curved end is located dorsally, curved toward the left side of the cell and ornamented with several small bulging folds (Fig. 4, b-d and f), whereas the long and narrow smooth end is lying ventrally (Fig. 4, a-c). The APC is enclosed by four apical plates that form a distinctive rim bordering the Po plate. This rim is well-developed on the dorsal side of the cell, but rather smoothed ventrally (Fig. 4). The first apical plate (1') is irregularly shaped, polygonal and elongated. It has a deep asymmetrical notch in its upper part, into which the Po plate fits,

234 whereas its posterior end is pointed and contacts the two sulcal plates Sa and Sd (Figs. 2, a, c and e; 3, a and d; 4, a and c). The second and fourth apical plates ( $2^{\prime}$ and $\left.4 '\right)$ are dorsoventrally

236 elongated, crescent-shaped and encircle the Po plate on its left and right sides (Figs. 2, c-f; 4c).

237 Owing to the prominent reticulate ornamentation of the thecal surface that obscure the sutures

238 between small epithecal plates, they were hardly distinguished with SEM, but were revealed in 239 calcofluor-stained cells. Thanks to the observation of the epithecal plate pattern with 
epifluorescence microscopy, three small plates were identified in the dorsal side of the epitheca

(Fig. 2, d and f). The third apical plate (3') is the smallest of the apical series, pentagonal and

242 located dorsally; it is adjoining with the Po plate between 2 ' and 4' plates, and bears only two

243 polygonal depressions (Figs. 2, $\mathrm{d}$ and f; 4, $\mathrm{f}$ and g). There are two small anterior intercalary

244 plates (1a and 2a), which are contiguous and located dorsally. The 1a plate is the smallest,

245 pentagonal, and contacts with $2^{\prime}, 3^{\prime}, 2 \mathrm{a}, 2^{\prime \prime}$ and $3^{\prime \prime}$. The 2 a plate is hexagonal and

246 characteristically ornamented with several polygonal depressions partly or completely

247 surrounded by prominent crest-like rims. It contacts with 1a, 3', 4', 3", 4" and 5" (Figs. 2, d and

$248 \mathrm{f} ; 4, \mathrm{c}, \mathrm{d}, \mathrm{f}$ and $\mathrm{g})$. The precingular series consists of six plates $\left(1^{\prime \prime}-6^{\prime \prime}\right)$, which are more or less

249 trapezoidal in shape. The first and sixth precingular plates are largest of the precingular series, lie

250 ventrally, and together with the first apical plate form the ventral part of the epitheca, while $2^{\prime \prime}$ -

2515 " plates are located on the dorsal side of the epitheca (Figs. 2, c and d; 4, c and d).

252 The cingulum is wide, completely encircling the cell and consists of six plates (1c-6c).

253 The first, second and sixth cingular plates are large, while the other cingular plates are smaller

254 and roughly similar in size. The right side of the first cingular plate (1c) is deeply notched in the

255 upper part, into which the anterior sulcal plate fits (Figs. 2, a-d and g; 4, a-d).

256 The sulcus consists of four plates (Figs. 2, a and g; 3, d and e; 5a). The small anterior

257 sulcal plate (Sa) almost completely invades the upper right corner of the first cingular plate (1c)

258 and touches the end of the first apical plate $\left(1^{\prime}\right)$ on the left. The relatively large right sulcal plate

$259(\mathrm{Sd})$ is six-sided and elongated, with a convex left border and a concave right one. It partly

260 invades the epitheca and touches the end of the first apical plate (1') on the right. The Sd plate

261 contacts the right end of the cingulum (6c), the $6 "$ plate and the 6 "' plate. The left sulcal plate

262 (Ss) is small, rectangular and located posterior to Sa touching the lower right side of the 1c, the

263 upper right side of the first postcingular plate (1"') and the top of the posterior sulcal plate. The

264 posterior sulcal plate $(\mathrm{Sp})$ is the largest of the sulcal series, occupying a considerable portion of

265 the sulcus. The Sp plate is long, five-sided, and wider toward the posterior and elongates from 
the Sd and Ss to the antapex. Its lateral sides contact the first $\left(1^{\prime \prime \prime}\right)$ and sixth $\left(6^{\prime \prime \prime}\right)$ postcingular

267 plates, and its wide posterior end is in contact mainly with the first antapical plate $\left(1^{\prime \prime \prime \prime}\right)$ and partly with the posterior intercalary plate (1p). Flagella pore(s) are obscured from view and are not identified.

The hypotheca consists of eight plates, comprising six postcingular plates $\left(1^{\prime \prime \prime}-6^{\prime \prime \prime}\right)$, one posterior intercalary plate $(1 \mathrm{p})$ and one antapical plate $\left(1^{\prime \prime \prime \prime}\right)$ (alternative interpretation of the hypothecal plate tabulation is discussed below). The large and oblong first (1"') and sixth (6"') postcingular plates elongate along the sulcus, occupying nearly the entire ventral part of the hypotheca (Figs. 2, a and g; 3, a, d and e; 5a; 6, a and d), whereas the other hypothecal plates are located dorsally (Figs. 2b; 3, b, c and f; 6, b and d) and asymmetrically arranged. The 2"' plate is the longest of the postcingular series and lie dorsally along the left lateral side of the hypotheca. The $3^{\prime \prime \prime}$ plate is the largest of the postcingular series. It is asymmetrically shaped, five-sided, with almost straight left lateral side and concave right one, into which the fourth postcingular plate $\left(4^{\prime \prime \prime}\right)$ fits. In contrast with the $2^{\prime \prime \prime}$ and $3^{\prime \prime \prime}$ plates that elongate through the whole hypotheca, the 4"' and 5"' plates are much shorter and extend one half of the whole way from the cingulum to the antapex. The 4"' plate is small, narrowly elongated and four-sided, with convex left lateral side. The $5^{\prime \prime \prime}$ plate is almost quadrate. There is one posterior intercalary plate (1p) that is located dorsally in the right posterior half of the hypotheca (Figs. 2, a and b; 3, b, c, e and f; 6, a, b and d). The $1 \mathrm{p}$ plate is large, six-sided, and contacts with $3 "$ "', 4 "', $5^{\prime \prime \prime}$ and $6^{\prime \prime \prime}$ postcingular plates, with antapical plate $\left(1^{\prime \prime \prime \prime}\right)$, and with posterior sulcal plate $(\mathrm{Sp})$. The $1 \mathrm{p}$ plate is ornamented with a single short claw-shaped antapical spine (Figs. 3, a and b; 5g). Only one five-sided antapical plate $\left(1^{\prime \prime \prime \prime}\right)$ with concave ventral side is present (Figs. 2, a and b; 3, b, e and f; 5a; 6, a, b and d). The thecal surface is highly and variously ornamented. Dorsal and ventral cell sides differ in ornamentation, and some plates are peculiarly decorated. The thecal surface of the convex dorsal side is reticulate, strongly ornamented with polygonal depressions (Figs. 3, b, c and f; 4, f and $\mathrm{g} ; 5, \mathrm{~b}, \mathrm{c}$ and $\mathrm{f} ; 6 \mathrm{~b}$ ). Dorsal polygonal depressions with diameter ranging between 0.48-1.6 
$\mu \mathrm{m}(1.27 \pm 0.26 \mu \mathrm{m}, \mathrm{n}=24)$ are closely appressed, deep, with well-developed raised and

293 crenulated sides. Most of the depressions contain from 3 up to 15 small pores of different size

294 (ranging from 0.11 to $0.16 \mu \mathrm{m}$ in diameter) at the bottom, however, there are depressions without pores (Fig. 5, b, c and f-i). The 2a plate on the dorsal side of the epitheca bears several depressions surrounded by prominent crest-like rims (Figs. 4, c-f; 5h). The thecal surface of the ventral side is foveate, ornamented with randomly scattered depressions, which are connected by incomplete ridges (Figs. 3, a and d; 5, a, d and e; 6a). Ventral depressions are shallower than dorsal ones, with smooth sides, round to oval, with diameter ranging between $0.62-0.87 \mu \mathrm{m}$ $(0.78 \pm 0.08 \mu \mathrm{m}, \mathrm{n}=14)$, containing $4-12$ small pores at the bottom. There are 5-7 larger depressions located ventrally near the cell margins (Figs. 2a; 5e; 6a). They are ovate, 1.0-2.2 $\mu \mathrm{m}$ in diameter, perforated by $27-45$ small pores forming a sieve-like bottom. The sulcal plates are ornamented almost like other ventral thecal plates, but depressions are smaller and less densely arranged, except for Sa plate, which is devoid of ornamentation at all (Figs. 2g; 3, a and d; 5a). The cingular plates possess shallow depressions; however, they are less developed than those on other plates (Fig. 4, a-d). d), but they are narrow and smooth in younger specimens (Fig. 4, b and f).

Known distribution and occurrence: A. reticulatum was recorded from two closely spaced

311 localities of the Jordanian coast (the Gulf of Aqaba, northern Red Sea) in carbonate coral sands.

312 This species occurred rarely, being found in three samples of 22 sediment samples collected at

313 different times. The species has been observed in very low cell densities in comparison with

314 many other sand-dwelling dinoflagellates at this sampling site.

316 Swimming behavior: Our observations of $A$. reticulatum at low magnification revealed that 317 normally live cells slowly swim close to the substrate surface ventral side down, in a relatively 
318 straight course, occasionally changing direction. Being disturbed, the cell immediately presses

319 itself to the bottom with its ventral side and stands still for several minutes.

Sequence analysis and molecular phylogeny

Two identical sequences of the SSU rDNA were independently acquired from two isolated cells of Ailadinium reticulatum collected in 2010 and 2011. Additionally, two identical sequences of the LSU rDNA were independently acquired from two isolated cells of $A$. reticulatum collected in 2011. Sequences were deposited to GenBank under the accession numbers KJ187034, KJ187035 (SSU) and KJ187036, KJ187037 (LSU).

In phylogenies inferred from SSU and LSU rDNA, sequences of $A$. reticulatum formed a fully supported clade among dinoflagellates. However, in both cases, the placement of this clade was unclear and not supported (Figs 7 and 8). Consequently, no clear relationships with Ailadinium and other genera can be ascertained from molecular data. In the SSU rDNA phylogeny, the clade of $A$. reticulatum branched as a sister clade to Amphidiniella sedentaria Horiguchi and Pileidinium ciceropse Tamura et Horiguchi but this position is not supported (Fig. 7). In the LSU rDNA phylogeny, the clade of A. reticulatum branched at the base of the

334 Gonyaulacales clade but without statistical support (Fig. 8).

DISCUSSION

Alternative plate pattern interpretation

As with many other benthic dinoflagellates, which often possess an unusual plate pattern, the thecal tabulation of Ailadinium reticulatum is rather difficult to interpret, and an alternative

340 pattern can be proposed. In particular, the hypothecal plate arrangement and the sulcal area can

341 be interpreted differently than we have described previously.

To facilitate the further comparison between A. reticulatum and previously described taxa, Kofoidian system of plate tabulation (Kofoid 1909, 1911) was used initially for the 
344 hypotheca. In terms of Kofoidian system, the large plate located dorsally in the right posterior

345 half of the hypotheca is interpreted by us as posterior intercalary plate (1p) because of its rather

346 lateral than antapical position, as in some gonyaulacoid genera (Fensome et al. 1993). However,

347 following Balech's modification of the Kofoidian system, in which the posterior intercalary

348 series is defined as 'those touching neither the cingulum nor the sulcus' (Balech 1980), the

349 posterior intercalary plate $1 \mathrm{p}$ may be reassigned as an antapical plate because of its contact with

350 posterior sulcal plate. The hypotheca then possesses two antapical plates, of which the second

351 antapical plate $2^{\prime \prime \prime \prime}$ is homologues of the $1 \mathrm{p}$. Alternatively, the hypothecal plate tabulation of $A$.

352 reticulatum may be interpreted as $6^{\prime \prime \prime}, 0 \mathrm{p}, 2^{\prime \prime \prime \prime}$.

353 A. reticulatum possesses a rather simple sulcal area including four sulcal plates that is

354 peculiar among dinoflagellates. However, owing to the rather asymmetrical structure of the

355 sulcus and an unclear position of the flagellar pore, the sulcal plate arrangement may be

356 subjected to different interpretation. In fact, the only two large sulcal plates are clearly visible,

357 whereas two smaller plates are almost obscured in view and arranged inside the pocket-like

358 upper part of the sulcus being overlapped by the larger sulcal plates. One more peculiarity of the

359 sulcal area in $A$. reticulatum is that there are two upper sulcal plates touching the epitheca, but

360 only one of them also contacts the proximal end of the cingulum, namely Sa in our interpretation

361 in agreement with Graham (1942). The second upper sulcal plate was interpreted here as the

362 right sulcal plate (Sd) because of its somewhat right position as described in Amphidiniopsis

363 uroensis Toriumi, Yoshimatsu et Dodge (Toriumi et al. 2002). However, given rather anterior

364 location in contact with epitheca in both the upper sulcal plates, they may also be interpreted

365 alternatively as the anterior sulcal complex composed of the larger right anterior sulcal plate Sad

366 (Sd in our previous interpretation) and the smaller left anterior sulcal plate Sas (Sa in previous

367 interpretation). We do not exclude the presence of one more sulcal plate inside the pocket-like

368 upper part of the sulcus. 
371 Being observed under light microscopy, cells of Ailadinium reticulatum seem to be similar to

372 dorsoventrally compressed members of the genus Amphidiniopsis Wołoszyńska with respect to

373 overall cell shape, cell proportion, size and outline of epitheca, ascending cingulum and often

374 strong thecal ornamentation. The plate tabulation of Ailadinium reticulatum in Balech's system

375 (APC, 4', 2a, 6", 6c, 4s, 6"', 2'"') somewhat resembles the overall plate arrangement of

376 Amphidiniopsis described as APC, 3-4', 1-3a, 6-8", 3-8c, 3-5s, 5(6)"'", 2"'"' (Hoppenrath 2000a;

377 Toriumi et al. 2002; Hoppenrath et al. 2009). Precingular series of A. cristata Hoppenrath, $A$.

378 korewalensis Murray et Patterson, A. pectinaria Toriumi, Yoshimatu et Dodge and A. uroensis

379 Toriumi, Yoshimatu et Dodge consists of six plates (6") as in Ailadinium reticulatum, but these

380 species differ in number and arrangement of the apical intercalary plates possessing one (in case

381 of $A$. cristata) or three (in A. korewalensis, A. pectinaria and A. uroensis) rather than two

382 intercalary plates. A. aculeata Hoppenrath, A. hexagona Yoshimatsu, Toriumi et Dodge, A.

383 hirsuta (Balech) Dodge and A. konovalovae Selina et Hoppenrath are all rather similar to

384 Ailadinium reticulatum in arrangement of the apical and intercalar series (4', 2a), but they differ

385 in possessing seven rather than six precingular plates. Thus, none of these species exactly

386 matches the epithecal pattern of Ailadinium reticulatum. Moreover, Amphidiniopsis species

387 differ significantly from Ailadinium reticulatum in hypothecal plate pattern, possessing five

388 rather six postcingular plates and two symmetrically arranged dorsally antapical plates, as well as

389 in the morphology of APC, cingulum and sulcus. Finally, in contrast to photosynthetic

390 Ailadinium reticulatum, Amphidiniopsis species are all heterotrophic (Hoppenrath 2000a; Murray

391 and Patterson 2002; Toriumi et al. 2002; Hoppenrath et al. 2009; Selina and Hoppenrath 2013).

392 The species most closely morphologically related to Ailadinium reticulatum by the plate

393 pattern is the small, scanty ornamented sand-dwelling Amphidiniella sedentaria, the type species

394 of the monotypic genus (Horiguchi 1995). Despite the conspicuous difference in the cell size and

395 thecal ornamentation, both species are sand-dwelling, photosynthetic, with similar shape, small 
epitheca and large hypotheca. In both species, the cells are dorsoventrally compressed and

397 possess the ascending cingulum, widened posteriorly sulcus, and pyrenoid(s). Ailadinium

398 reticulatum has a plate tabulation interpreted in Balech's system, 4', 2a, 6", 6c, 4s, 6"', 2"'",

399 notably similar to that of $A$. sedentaria (4', 1a, 7", 5c, 4s, 6"'", 2'"'). The epithecal plate

400 arrangement is rather similar for both species in respect of the total number of the epithecal

401 plates and their pattern. Like to Ailadinium reticulatum, A. sedentaria possesses four apical

402 plates, of which the $1^{\prime}$ is asymmetrical and notched at its upper part, and $3^{\prime}$ is the smallest of the

403 series. Both species have peculiarly ornamented dorsally located anterior intercalary plate, but

404 differ from each other in the total number of plates in the intercalary and precingular series: $A$.

405 sedentaria has only one relatively large anterior intercalary plate and seven rather six precingular

406 plates. Ailadinium reticulatum differs from A. sedentaria in lacking of the ventral pore. Both

407 species have a rather similar composition of the apical pore complex consisted of the apical pore

408 plate with slit-like apical pore and the cover plate, but A. sedentaria has a bean-shaped Po

409 compared with narrowly elongated hook-shaped APC in Ailadinium reticulatum. Both species

410 have the same plate arrangement in the hypotheca that is conventionaly considered as most

411 conservative diagnostic feature in thecate dinoflagellates (Fensome et al. 1993).

412 Reticulated thecal morphology is a rather frequent character among both planktonic and

413 benthic dinoflagellates. Similar to Ailadinium, a highly foveate-reticulate ornamentation has been

414 described in some species of the genus Sinophysis Nie \& Wang, including S. canaliculata Quod,

415 Ten-Hage, Turquet, Mascarell \& Couté and S. microcephala Nie \& Wang (Nie and Wang 1944;

416 Quod et al. 1999). The similar thecal ornamentation has been reported in benthic dinoflagellates

417 Pileidinium ciceropse, Roscoffia capitata Balech, Cabra reticulata Chomérat et Nézan,

418 Thecadinium arenarium Yoshimatsu, Tourimi et Dodge (Hoppenrath and Elbrächter 1998;

419 Yoshimatsu et al. 2004; Tamura and Horiguchi 2005; Chomérat and Nézan 2009), in some of

420 benthic Prorocentrum Ehrenberg (e.g. Hoppenrath et al. 2013), as well as in a number of

421 plankton dinoflagellates of the genera Dinophysis Ehrenberg, Gonyaulax Diesing, Heterodinium 
Kofoid, Protoceratium Bergh and others (e.g. Kofoid 1906, 1911; Kofoid and Michener 1911;

423

424

425

426

427

428

430

432

433

434

435

436

437

Röder et al. 2012). Most of species with highly reticulate theca are ornamented with more or less deep polygonal depressions possessing typically a single central pore, whereas the reticulations of $A$. reticulatum are unusually perforated with numerous very small pores at the bottom. Among the sand-dwelling species, Thecadinium yashimaense Yoshimatsu, Toriumi et Dodge (syn. T. mucosum Hoppenrath et Taylor; T. foveolatum Bolch) is the only species possessing the similar type of depressions that were described as large round openings having 4-10 small pores at the bottom (Hoppenrath et al. 2004). Additionally, newly described benthic dinoflagellate Madanidium loirii Chomérat possesses an area closely arranged small pores at the bottom of shallow depressions (Chomérat and Bilien 2014). Some benthic Prorocentrum species possess the special features on their thecal surface. $P$. panamense Grzebyk, Sako et Berland and $P$. pseudopanamense Chomérat et Nézan have a single large roundish depression with sieve-like bottom perforated by numerous small pores (Grzebyk et al. 1998; Chomérat et al. 2011). Moreover, the pair of large pores at the lower dorsal side in Adenoides eludens (Herdman) Balech contains the similar sieve-plates (Hoppenrath et al. 2003, 2013). The marginal depressions of $P$. consutum Chomérat et Nézan and Pileidinium ciceropse contain 3-4 small pores (Tamura and Horiguchi 2005; Mohammad-Noor et al. 2007; Chomérat et al. 2010b). The possible involvement of these specific features with sieve-like bottom into the mucus excretion has been hypothesized in T. yashimaense (Hoppenrath et al. 2004) and may be supported by our recent observations. Probably, the marginal large depressions with numerous pores at the bottom that were found on the thecal surface in $A$. reticulatum could provide the momentary discharge of mucus supporting the rapid and durable attachment of cell to the substrate. A similar manner of connection with substrate has been found recently in cells of $P$. panamense that were commonly observed in culture as attached to the bottom at their antapical ends with mucus secreted from the small pores in the roundish depression with sieve-like bottom on the right valve (unpublished observation of the first author). 

the apical pore complex. The composition of the APC in A. reticulatum resembles that of gonyaulacoids in which a canal plate (X) is absent (Fensome et al. 1993; Steidinger and Tangen 1996). The asymmetrical shape of the pore plate and presence of the cover plate covering the apical pore is similar to that observed in members of the family Goniodomataceae Lindermann such as Alexandrium Halim, Goniodoma Stein and Pyrodinium Plate (e.g. Dodge and Hermes 1981; Steidinger and Tangen, 1996), but the APC of A. reticulatum differs from all these taxa in having a more narrow and elongated outline. This unusual strongly elongated shape reminds that of some members in the peridinioid family Podolampaceae Lindermann such as Gaarderia, Heterobractum and Mysticella Carbonell-Moore (1994), but they all have a canal plate. Although the apical pore in $A$. reticulatum is completely obscured by the cover plate, it seems to have the same path as its covering plate, being long with hooked end. The hooked end of the apical pore in $A$. reticulatum is bent towards the left cell side that is side-reversed to all other dinoflagellates bearing hook-shaped apical pore including species belonging to the genus Gambierdiscus Adachi and Fukuyo (e.g. Litaker et al. 2009), Fragilidium Balech ex Loeblich III (e.g. Balech 1959; Nézan and Chomérat 2009) and some Thecadinium species, e.g. T. inclinatum Balech and T. kofoidii (Herdman) Larsen (Hoppenrath 2000b; Yoshimatsu et al. 2004). From the APC morphology, the most similar species to A. reticulatum is Cabra aremorica Chomérat, Couté et Nézan that also has the unusual side-reversed hook in APC (Chomérat et al. 2010a). anterior intercalary plate (2a) that distinctively differs from the surrounding epithecal plates in its 469 ornamentation. The similar peculiarly decorated epithecal plates has been described in a few sand-dwelling dinoflagellates including some of Thecadinium (T. arenarium, T. ovum, T. striatum Yoshimatsu, Toriumi et Dodge, T. yashimaense), and A. sedentaria (Horiguchi 1995; Hoppenrath et al. 2004; Yoshimatsu et al. 2004). 

peculiar placement of the posterior intercalary or second antapical plate (1p or $2^{\prime \prime \prime \prime}$ depending on the interpretation) that is located dorsally in the right posterior half of the hypotheca. This contradicts the typical hypothecal plate pattern of gonyaulacaleans with usually ventrally located single posterior intercalary plate at the left side of the hypotheca (Fensome et al. 1993). Owing to its side-reversed position, this plate is homologues of the $2^{\prime \prime \prime \prime}$ in Balech's system. The dorsal placement of the posterior intercalary plate(s) is unusual among gonyaulacaleans and the only has been described previously in Pyrophacus Stein (e.g. Fensome et al. 1993), Adenoides Balech (Hoppenrath et al. 2003), and Amphidiniella Horiguchi (1995).

\section{Phylogeny}

Molecular analyses revealed that Ailadinium reticulatum forms a new clade within dinoflagellates which is not clearly related to any known genus. This result strongly supports the erection of the new genus Ailadinium that appears genetically distant from all other dinoflagellates and forms a new lineage. Moreover, this genus corresponds to a new dinoflagellate lineage which is, at the moment, not possible to assign in any particular family or order with the genetic markers used. Notwithstanding the absence of support in the LSU phylogeny, the analysis inferred from this gene suggests that it could be related to Gonyaulacales, but this result needs further confirmation.

The newly described herein genus Ailadinium joins a specific group of 'strange' thecate sanddwelling dinoflagellates, which also includes Adenoides, Amphidiniella, Cabra Murray et Patterson, Herdmania Dodge, Madanidinium Chomérat et Bilien, Pileidinium Tamura et Horiguchi, Plagiodinium Faust et Balech, Planodinium Saunders et Dodge, Pseudothecadinium Hoppenrath et Selina, Rhinodinium Murray et al., Roscoffia Balech and Sabulodinium Saunders 
recorded. Additionally, unusual thecal patterns found in these 'strange' dinoflagellates do not

500 provide clear evidences for their systematic position based on existing taxonomic criteria.

501 Moreover, because of scarcely available molecular data, their phylogenetic affinities within the

502 Dinophyceae are not always clearly determined (Hoppenrath et al. 2003; Tamura and Horiguchi

503 2005; Hoppenrath et al. 2007; Yamaguchi et al. 2011; Chomérat and Bilien 2014).

$504 \quad$ The resemblance between Ailadinium reticulatum and dorsoventrally compressed

505 Amphidiniopsis species has been shown as superficial. Based on morphology alone, the plate

506 pattern found in Ailadinium reticulatum has an affinity to the basic plate tabulation in the

507 Gonyaulacales (Fensome et al. 1993) with respect to its overall strongly asymmetry,

508 characteristically shaped first apical plate and APC, and possessing four apical, six pre- and

509 postcingular, one posterior intercalary and one antapical plates. Surprisingly, a minute benthic

510 dinoflagellate Amphidiniella sedentaria has been found to be most closely related to large and

511 heavily ornamented Ailadinium reticulatum by the similarity of shape, in the APC composition

512 and the total number of the epithecal plates, in possessing of small and peculiarly ornamented

513 apical intercalary plate, and in the same pattern of the hypothecal plates. However, Ailadinium

514 reticulatum and Amphidiniella sedentaria differ in the number of apical intercalary, precingular

515 and cingular plates and largely in size; therefore, we decided to consider them as members of

516 two different genera and to propose the erection of the new genus Ailadinium. Based on

517 morphological analysis, Horiguchi assigned the genus Amphidiniella to the Gonyaulacales

518 (Horiguchi 1995), however, this conclusion has not been supported by further phylogenetic study

519 (Tamura and Horiguchi 2005). Similarly, the affiliation of Ailadinium to the Gonyaulacales was

520 not supported in our phylogenetic analysis. For now, we can only conclude that Ailadinium

521 belongs to Peridiniphycideae incertae sedis and cannot be assigned to any existing supregeneric

522 taxa. 
526 We highly appreciate Dr. Igor Polikarpov (Kuwait Institute for Scientific Research, Kuwait)

527 valuable help with sampling and overall support during this work. We are grateful to anonymous 528 reviewers for their detailed and constructive comments. The authors wish to thank Mrs. G. Bilien 529 (IFREMER LER BO, France) for her assistance with the molecular work and Mr. N. Gayet 530 (REM/EEP/LEP IFREMER Brest Center, France) for his help with SEM. The authors are 531 grateful to Prof. Thomas S. Parker (North Carolina State University, USA) for his comments and 532 advice on the ancient Jordanian toponomy. This study was supported in part by the Foreign Fellow Scientist Program at the French Research Institute for Exploitation of the Sea (IFREMER, Concarneau, France).

\section{REFERENCES}

Al-Rousan, S., Felis, T., Manasrah, R. \& Al-Horani, F. 2007. Seasonal variations in the stable oxygen isotopic composition in Porites corals from the northern Gulf of Aqaba, Red Sea.

Geochem. J. 41:333-340.

Al-Zibdah, M. K., Damhoureyeh, S. A. \& Badran, M. I. 2007. Temporal variations in coral reef health at a coastal industrial site on the Gulf of Aqaba, Red Sea. Oceanologia 49(4):565-578.

Balech, E. 1956. Étude des dinoflagellés du sable de Roscoff. Rev. Algol. 2(1-2):29-52.

Balech, E. 1959. Two new genera of dinoflagellates from California. Biol. Bull. 116:195-203.

Balech, E. 1980. On thecal morphology of dinoflagellates with special emphasis on circular and sulcal plates. An. Centro Cienc. del Mar y Limnol. Univ. Nal. Auton. Mexico 7(1):57-68. 
552 Balech, E. 1988. Los dinoflagelados del atlantico sudoccidental. Publ. Esp. Inst. Español

553 Oceanogr. Madrid 1:1-310.

554

555 Carbonell-Moore, M. C. 1994. On the taxonomy of the family Podolampaceae Lindemann

556 (Dinophyceae) with descriptions of three new genera. Rev. Paleobot. Palynol. 84:73-99.

557

558 Catania, D. 2012. The prevalence of benthic dinoflagellates associated with ciguatera in the

559 Central Red Sea. MSc thesis. King Abdullah University of Science and Technology, Saudi

$560 \quad$ Arabia, 40 pp.

561

562 Chomérat, N. \& Bilien, G. 2014. Madanidinium loirii gen. et sp. nov. (Dinophyceae), a new

563 marine benthic dinoflagellate from Martinique Island, Eastern Caribbean. Eur. J. Phycol.

$564 \quad 49(2): 165-178$.

565

566 Chomérat, N. \& Couté, A. 2008. Protoperidinium bolmonense sp. nov. (Peridiniales,

567 Dinophyceae), a small dinoflagellate from a brackish hypereutrophic lagoon (South of France).

568 Phycologia 47:392-403.

569

570 Chomérat, N., Couté, A. \& Nézan, E. 2010a. Further investigations on the sand-dwelling genus

571 Cabra (Dinophyceae, Peridiniales) in South Brittany (northwestern France), including the

572 description of C. aremorica sp. nov. Mar. Biodiv. 40(2):131-142.

573

574 Chomérat, N. \& Nézan, E. 2009. Cabra reticulata sp. nov. (Dinophyceae), a new sand-dwelling

575 dinoflagellate from the Atlantic Ocean. Eur. J. Phycol. 44:415-423.

576 
578 sp. nov. (Dinophyceae, Prorocentrales), a new benthic dinoflagellate species from Kuwait

579 (Arabian Gulf). J. Phycol. 48:211-21.

580

581 Chomérat, N., Sellos, D. Y., Zentz, F. \& Nézan, E. 2010b. Morphology and molecular phylogeny

582 of Prorocentrum consutum sp. nov. (Dinophyceae), a new benthic dinoflagellate from South

583 Brittany (northwestern France). J. Phycol. 46:183-94.

584

585 Chomérat, N., Zentz, F., Boulben, S., Bilien, G., van Wormhoudt, A. \& Nézan, E. 2011.

586 Prorocentrum glenanicum sp. nov. and Prorocentrum pseudopanamense sp. nov.

587 (Prorocentrales, Dinophyceae), two new benthic dinoflagellate species from South Brittany

588 (northwestern France). Phycologia 50(2):202-214.

589

590

Dodge, J. D. \& Hermes, H. B. 1981. A scanning electron microscopical study of the apical pores

591 of marine dinoflagellates (Dinophyceae). Phycologia 20(4):424-430.

592

593 Faust, M. A. \& Balech, E. 1993. A further SEM study of marine benthic dinoflagellates from a

594 mangrove island, Twin Cays, Belize, including Plagiodinium belizeanum gen. et sp. nov. J.

595 Phycol. 29:826-832.

596

597 Faust, M. A., Litaker, R. W., Vandersea, M. W., Kibler, S. R. \& Tester, P. A. 2005.

598 Dinoflagellate diversity and abundance in two Belizean coral-reef mangrove lagoons: a test of

599 Margalef's Mandala. Atoll Research Bul. 534:104-131.

600 
601 Fensome, R. A., Taylor, F. J. R., Norris, D. R., Sargeant, W. A. S., Wharton, D. I. \& Williams, 602 G. L. 1993. A classification of living and fossil dinoflagellates. Micropaleontol. Spec. Publ. 7:1$603 \quad 351$.

604

605 Fritz, L. \& Triemer, R. E. 1985. A rapid simple technique utilizing calcofluor white MR2 for the 606 visualization of dinoflagellate thecal plates. J. Phycol. 21:662-664.

607

608 Fukuyo, Y. 1981. Taxonomical study on benthic dinoflagellates collected in coral reefs. Bull. 609 Jap. Soc. Sci. Fish. 47:967-978.

610

611 Graham, H. W. 1942. Studies in the Morphology, Taxonomy, and Ecology of the Peridiniales.

612 Carnegie Institution of Washington Publ. 542, Washington, 129 pp.

613

614 Grzebyk, D., Sako, Y. \& Berland, B. 1998. Phylogenetic analysis of nine species of

615 Prorocentrum (Dinophyceae) inferred from 18S ribosomal DNA sequences, morphological

616 comparisons, and description of Prorocentrum panamensis, sp. nov. J. Phycol. 34:1055-1068.

617

618 Guindon, S., Dufayard, J.-F., Lefort, V., Anisimova, M., Hordijk, W. \& Gascuel, O. 2010. New

619 algorithms and methods to estimate Maximum-Likelihood phylogenies: assessing the

620 performance of PhyML 3.0. Syst. Biol. 59:307-21.

621

622 Hoppenrath, M. 2000a. Taxonomische und ökologische Untersuchungen von Flagellaten mariner

623 Sande. Ph.D. dissertation, Biologische Fakultät, Universität Hamburg, Germany, 311 pp.

624 
625 Hoppenrath, M. 2000b. Morphology and taxonomy of the marine sand-dwelling genus

626 Thecadinium (Dinophyceae), with the description of two new species from the North German

627 Wadden Sea. Phycologia 39:96-108.

628

629 Hoppenrath, M., Chomérat, N., Horiguchi, T., Schweikert, M., Nagahama, Y. \& Murray S. 2013.

630 Taxonomy and phylogeny of the benthic Prorocentrum species (Dinophyceae) - a proposal and

631 review. Harmful Algae 27:1-28.

632

633 Hoppenrath, M. \& Elbrächter, M. 1998. Roscoffia capitata (Dinophyceae) refound: notes on 634 morphology and biology. Phycologia 37:450-457.

635

636 Hoppenrath, M., Horiguchi, T., Miyoshi, Y., Selina, M., Taylor, F. J. R. \& Leander, B. S. 2007.

637 Taxonomy, phylogeny, biogeography, and ecology of Sabulodinium undulatum (Dinophyceae),

638 including an emended description of the species. Phycol. Res. 55:159-175.

639

640 Hoppenrath, M., Koeman, R. P. T. \& Leander, B. S. 2009. Morphology and taxonomy of a new

641 marine sand-dwelling Amphidiniopsis species (Dinophyceae, Peridiniales), A. aculeata sp. nov.,

642 from Cap Feret, France. Mar. Biodiv. 39:1-7.

643

644 Hoppenrath, M., Saldarriaga, J. F., Schweikert, M., Elbrächter, M. \& Taylor, F. J. R. 2004.

645 Description of Thecadinium mucosum sp. nov. (Dinophyceae), a new sand-dwelling marine

646 dinoflagellate, and an emended description of Thecadinium inclinatum Balech. J. Phycol.

$647 \quad 40: 946-61$.

648 
Hoppenrath, M., Schweikert, M. \& Elbrächter M. 2003. Morphological reinvestigation and 650 characterization of the marine, sand-dwelling dinoflagellate Adenoides eludens (Dinophyceae).

651 Eur. J. Phycol. 38:385-394.

652

653

Hoppenrath, M. \& Selina, M. 2006. Pseudothecadinium campbellii gen. nov. sp. nov.

654 (Dinophyceae), a phototrophic, thecate, marine planktonic species found in the Sea of Okhotsk, 655 Russia. Phycologia 45:260-269.

656

657 Horiguchi, T. 1995. Amphidiniella sedentaria gen. et sp. nov. (Dinophyceae), a new sand658 dwelling dinoflagellate from Japan. Phycol. Res. 43:93-99.

659

660 Ismail, N. S. 1986. Community structure of macrobenthic invertebrates in sandy beaches of the 661 Jordan, Gulf of Aqaba, Red Sea. Int. Revue ges. Hydrobiol. 71(2):225-232.

662

663 Katoh, K. \& Standley, D. M. 2013. MAFFT multiple sequence alignment software version 7: 664 improvements in performance and usability. Mol. Biol. Evol. 30:772-80.

665

666 Kofoid, C. A. 1906. Dinoflagellata of the San Diego region. I. On Heterodinium, a new genus of 667 the Peridinidae. Univ. Calif. Publ. Zool. 2:341-368.

668

669 Kofoid, C. A. 1909. On Peridinium steini Jörgensen, with a note on the nomenclature of the 670 skeleton of the Peridinidae. Arch. Protistenk. 16:25-47.

671

672 Kofoid, C. A. 1911. Dinoflagellata of the San Diego region, IV. The genus Gonyaulax, with 673 notes on its skeletal morphology and a discussion of its generic and specific characters. Univ.

674 Calif. Publ. Zool. 8:187-286. 
676 Kofoid, C. A. \& Michener, J. R. 1911. New genera and species of dinoflagellates. No 22.

677 Reports on the Scientific Results of the Expedition to the Eastern Tropical Pacific in charge of 678 Alexander Agassiz, by the U. S. Fish Commission Steamer 'Albatross', from October, 1904, to 679 March, 1905, Lieut. Commander L. M. Garrett, U.S.N., commanding. Bull. Mus. Comp. Zoöl. 680 Harvard College 54:267-302.

681

682 Larsen, J. 1985. Algal studies of the Danish Wadden Sea II. A taxonomic study of psammobious 683 dinoflagellates. Opera Bot. 79:14-37.

684

685 Litaker R. W., Vandersea, M. W., Faust, M. A., Kibler, S. R., Chinain, M., Holmes, M. J., 686 Holland, W. C. \& Tester, P. A. 2009. Taxonomy of Gambierdiscus including four new species, 687 Gambierdiscus caribaeus, Gambierdiscus carolinianus, Gambierdiscus carpenteri and 688 Gambierdiscus ruetzleri (Gonyaulacales, Dinophyceae). Phycologia 48:344-390.

689

690 Mohammad-Noor, N., Daugbjerg, N., Moestrup, Ø. \& Anton, A. 2007. Marine epibenthic 691 dinoflagellates from Malaysia - a study of live cultures and preserved samples based on light and 692 scanning electron microscopy. Nord. J. Bot. 24:629-690.

693

694

Murray, S. 2009. Diversity and Phylogenetics of Sand-dwelling Dinoflagellates. VDM Verlag 695 Dr. Müller Aktiengesellschaft \& Co. KG, University of Sydney, Sydney, 213 pp.

696

697 Murray, S., Hoppenrath, M., Preisfeld, A., Larsen, J., Yoshimatsu, S.-A., Toriumi, S. \& 698 Patterson, D. J. 2006. Phylogenetics of Rhinodinium broomeense gen. et sp. nov., a peridinioid, 699 sand dwelling dinoflagellate (Dinophyceae). J. Phycol. 42:934-942. 
Murray, S. \& Patterson, D. J. 2002. Amphidiniopsis korewalensis sp. nov., a new heterotrophic

702 benthic dinoflagellate. Phycologia 41:382-388.

703

704

Murray, S. \& Patterson, D. J. 2004. Cabra matta, gen. nov., sp. nov., a new benthic,

705

heterotrophic dinoflagellate. Eur. J. Phycol. 39:229-234.

706

707

Nézan, E. \& Chomérat, N. 2009. Fragilidium duplocampanaeforme sp. nov. (Dinophyceae): a

708

new phagotrophic dinoflagellate from the French Atlantic coast. Eur. J. Protistol. 45:2-12.

709

710

Nézan, E. \& Chomérat, N. 2011. Vulcanodinium rugosum gen. et sp. nov. (Dinophyceae), un nouveau dinoflagellé marin de la côte méditerranéenne française. Cryptog. Algol. 32(1):3-18.

712

713 Nie, D. \& Wang, C.-C. 1944. Dinoflagellata of the Hainan Region. VIII. On Sinophysis

microcephalus, a new genus and species of Dinophysidae. Sinensia 15:145-151.

715

716

Parker, S. T. 1997. Preliminary report on the 1994 season of the Roman Aqaba Project. Bull. Am.

717 Schools Orient. Res. 305:19-44.

718

719

Posada, D. 2008. jModelTest: Phylogenetic model averaging. Mol. Biol. Evol. 25:1253-56.

720

721

Quod, J.-P., Ten-Hage, L., Turquet, J., Mascarell, G. \& Couté A. 1999. Sinophysis canaliculata

sp. nov. (Dinophyceae), a new benthic dinoflagellate from western Indian Ocean islands.

Phycologia 38:87-91.

724

725 Röder, K., Hantzsche, F. M., Gebühr, C., Miene, C., Helbig, T., Krock, B., Hoppenrath, M.,

726 Luckas, B. \& Gerdts, G. 2012. Effects of salinity, temperature and nutrients on growth, cellular 

70.

729

730

Ronquist, F. \& Huelsenbeck, J. P. 2003. MrBayes 3: Bayesian phylogenetic inference under mixed models. Bioinformatics 19:1572-74.

732

Saburova, M., Al-Yamani, F. \& Polikarpov, I. 2009. Biodiversity of free-living flagellates in

Kuwait's intertidal sediments. In Krupp, F., Musselman, L. J., Kotb, M. M. A. \& Weidig, I.

[Eds.] Environment, Biodiversity and Conservation in the Middle-East. Proceedings of the First Middle Eastern Biodiversity Congress. Aqaba, Jordan, 20-23 October 2008. Biorisk 3:97-110.

Saburova, M., Polikarpov, I. \& Al-Yamani, F. 2013. New records of the genus Gambierdiscus in marginal seas of the Indian Ocean. Mar. Biodiversity Rec. 6(e91):1-11.

740

741

Selina, M. S. \& Hoppenrath, M. 2013. Morphology and taxonomy of seven marine sanddwelling Amphidiniopsis species (Peridiniales, Dinophyceae), including two new species, $A$. konovalovae sp. nov. and A. striata sp. nov., from the Sea of Japan, Russia. Mar. Biodiv. 43:87104.

745

Steidinger, K. A. \& Tangen, K.1996. Dinoflagellates. In Tomas C. R. [Ed.] Identifying Marine Phytoplankton. Academic Press, San Diego, pp. 387-584.

Tamura, M. \& Horiguchi, T. 2005. Pileidinium ciceropse gen. et sp. nov. (Dinophyceae), a sanddwelling dinoflagellate from Palau. Eur. J. Phycol. 40:281-291. 
Tamura, K., Peterson, D., Peterson, N., Stecher, G., Nei, M. \& Kumar, S. 2011. MEGA5:

753

Molecular Evolutionary Genetics Analysis using Maximum Likelihood, evolutionary distance, and Maximum Parsimony methods. Mol. Biol. Evol. 28:2731-39.

Toriumi, S., Yoshimatsu, S. \& Dodge, J. D. 2002. Amphidiniopsis uroensis sp. nov. and Amphidiniopsis pectinaria sp. nov. (Dinophyceae): two new benthic dinoflagellates from Japan. Phycol. Res. 50:115-124.

Uhlig, G. 1964. Eine einfache Methode zur Extraktion der vagilen mesopsammalen Mikrofauna. Helgol. Wiss. Meeresunters. 11:178-85.

UNEP/IUCN 1988. Coral Reefs of the World. Volume 2: Indian Ocean, Red Sea and Gulf. UNEP Regional Seas Directories and Bibliographies. IUCN, Gland, Switzerland and Cambridge, UK/UNEP, Nairobi, Kenya.

Yamaguchi, A., Hoppenrath, M., Pospelova, V., Horiguchi, T. and Leander, B. S. 2011.

Molecular phylogeny of the marine sand-dwelling dinoflagellate Herdmania litoralis and an emended description of the closely related planktonic genus Archaeperidinium Jörgensen. Eur. J. Phycol. 46:98-112.

Yoshimatsu, S., Toriumi, S. \& Dodge, J. D. 2004. Morphology and taxonomy of five marine sand-dwelling Thecadinium species Dinophyceae from Japan, including four new species Thecadinium arenarium sp. nov., Thecadinium ovatum sp. nov., Thecadinium striatum sp. nov. and Thecadinium yashimaense sp. nov. Phycol. Res. 52:211-223. 


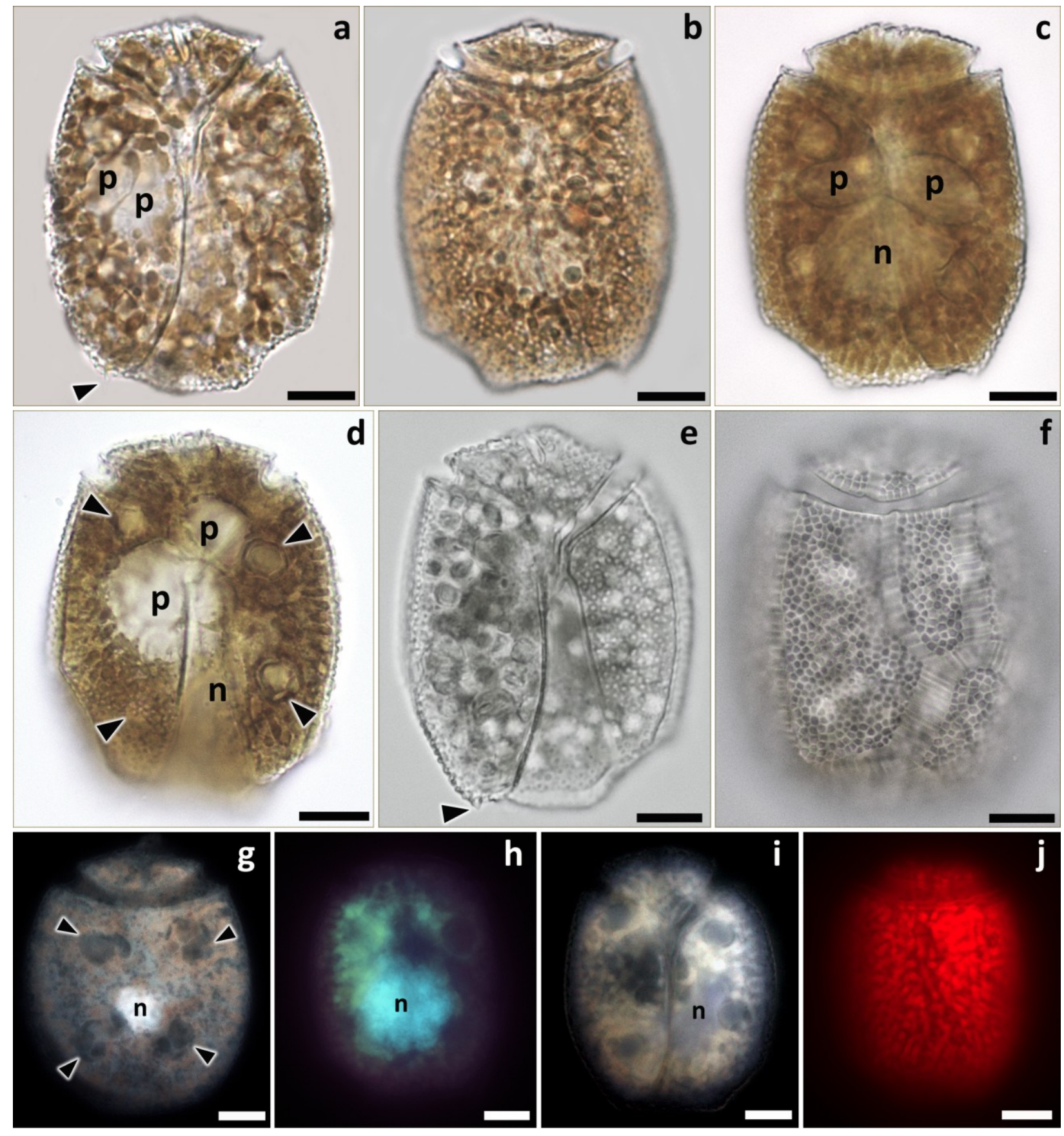

779 Fig. 1. Light micrographs of Ailadinium reticulatum gen. et sp. nov. from field samples. (a-d)

780 Bright field (BF) micrographs: (a) Ventral view, focus in the cell middle plane, showing

781 numerous chloroplasts, two small pusules (p) and asymmetrical antapical spine (arrowhead). (b)

782 Dorsal view, focus in the cell surface. Note the deeply indented cingulum and numerous colored

783 and colorless globules in the cytoplasm. (c, d) Dorsal view, focus in the cell middle plane, showing numerous chloroplasts, pusules (p), nucleus (n) and four pyrenoids at the periphery of the cell (arrowheads). (e, f) Differential interference contrast (DIC): (e) Ventral view showing the thecal ornamentation and asymmetrical antapical spine (arrowhead). (f) Dorsal view showing the thecal ornamentation. (g-i) Cells stained with DAPI and illuminated with UV light, showing nucleus (n), arrowheads point pyrenoids. (j) Cell illuminated with UV light, showing the chlorophyll autofluoresecence. Scale bar, $10 \mu \mathrm{m}$. 

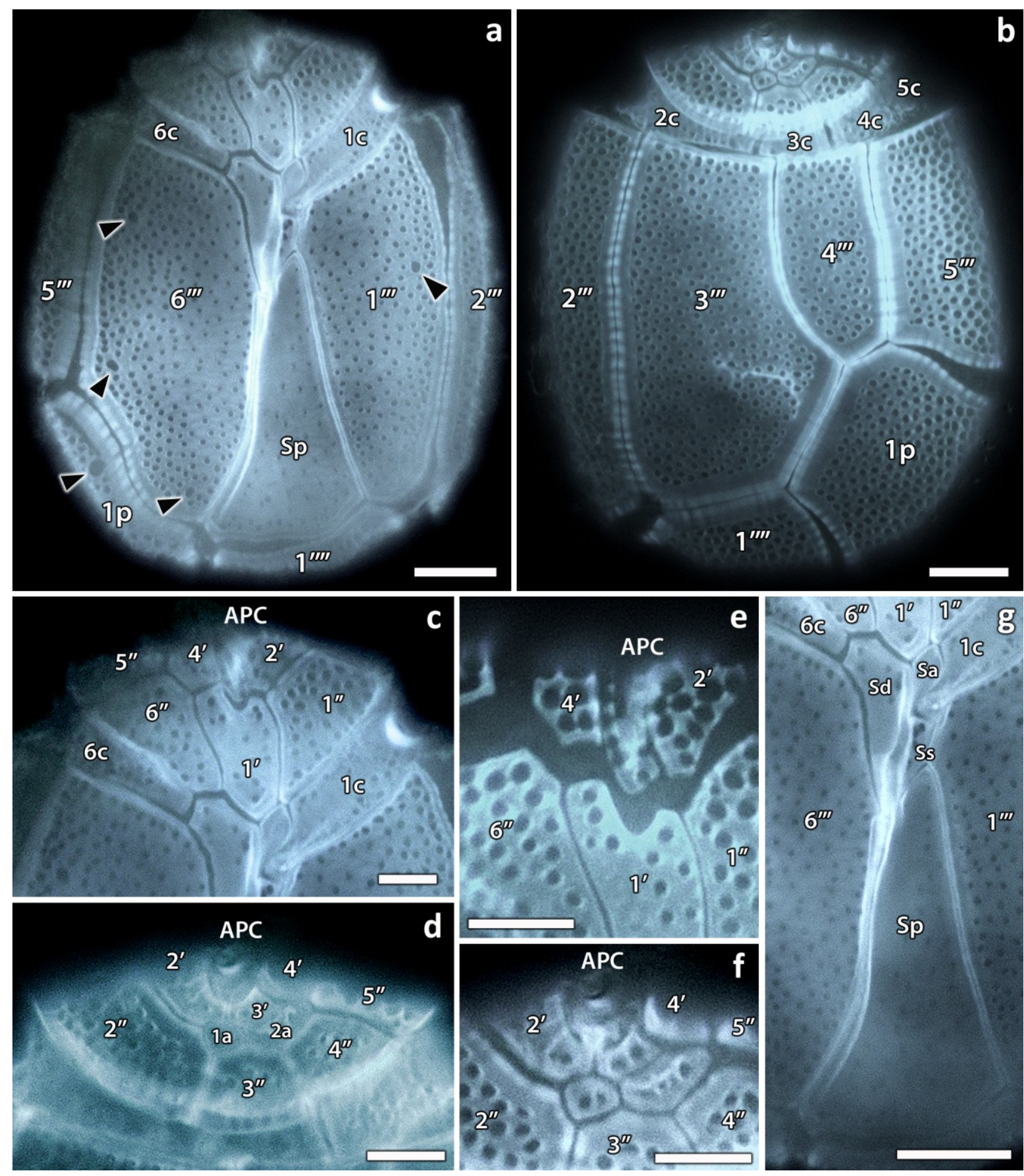

Fig. 2. Light micrographs of Ailadinium reticulatum gen. et sp. nov. (a-g) Cells stained with Calcofluor White and illuminated with UV light, showing the thecal plate pattern: (a) Ventral view of whole cell. Large marginal depressions are indicated by arrowheads. (b) Dorsal view of whole cell. (c) Detail of the ventral side of the epitheca. (d) Detail of the dorsal side of the epitheca. (e, f) APC and surrounded plates in ventral (e) and dorsal (f) views. (g) Detail of the sulcus with surrounded plates in ventral view. APC, apical pore complex; Po, apical pore plate; $\mathrm{cp}$, cover plate; 1-4', apical plate series; 1a-2a, anterior intercalary plates; $1-6^{\prime \prime}$, precingular plate series; 1-6c, cingular plate series; 1-6"', postcingular plate series; 1p, posterior intercalary plate; 1'"', antapical plate; Sa, anterior sulcal plate; Sd, right sulcal plate; Ss, left sulcal plate; Sp, posterior sulcal plate. Scale bars, $10 \mu \mathrm{m}$ in $(\mathrm{a}, \mathrm{b}, \mathrm{g})$ and $5 \mu \mathrm{m}$ in (c-f). 

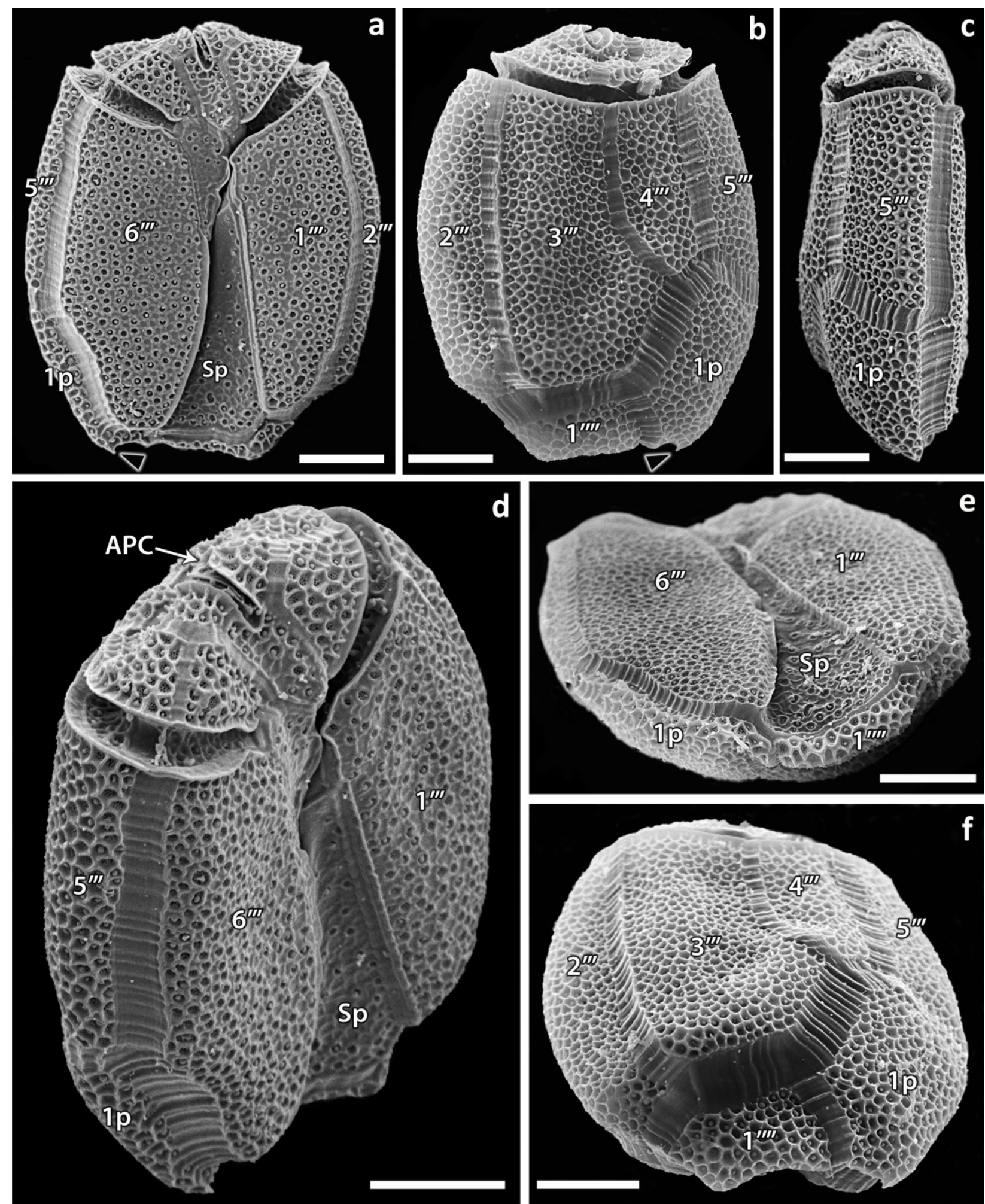

d
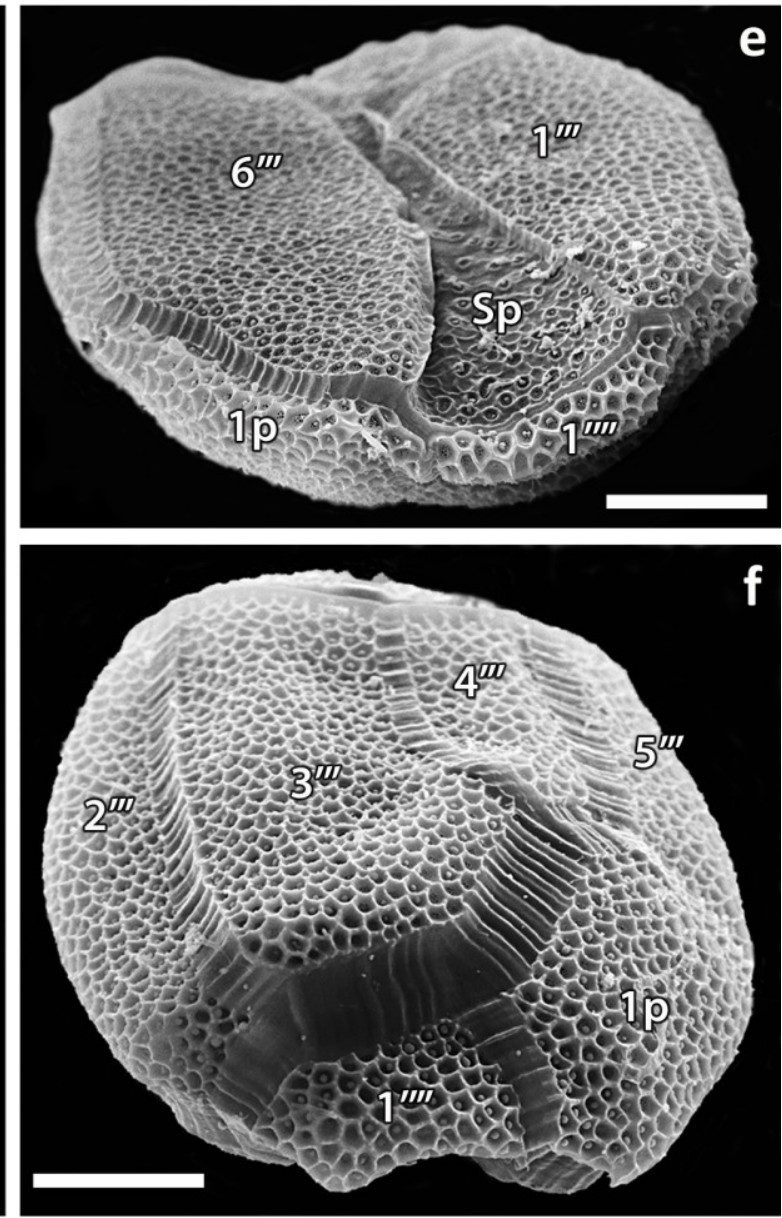

804

Fig. 3. Scanning electron micrographs of Ailadinium reticulatum gen. et sp. nov. (stub \# 

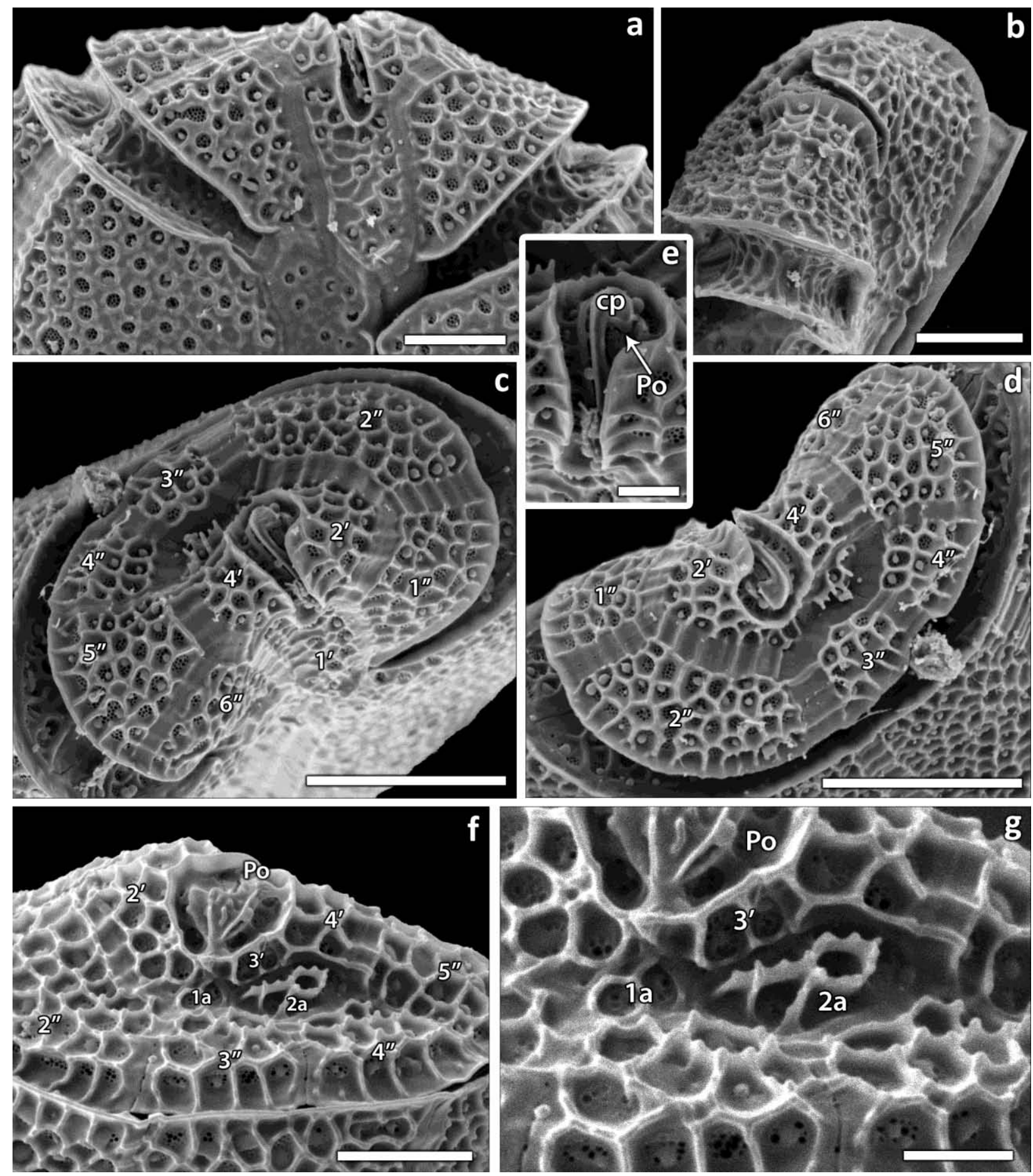

814

815 Fig. 4. Scanning electron micrographs of Ailadinium reticulatum gen. et sp. nov. (stub \#

816 CEDiT2014H35). (a-g) Epitheca: (a) Ventral view. (b) Oblique right lateral view. (c, d) Apical

817 views showing the epithecal plate pattern. (e) Detail of the apical view of the epitheca showing

818 the APC. (f, g) Details of the dorsal side of the epitheca showing the plate pattern. Scale bars, 10

$819 \mu \mathrm{m}$ in (c, d), $5 \mu \mathrm{m}$ in (a, b, f) and $2 \mu \mathrm{m}$ in (e, g). 

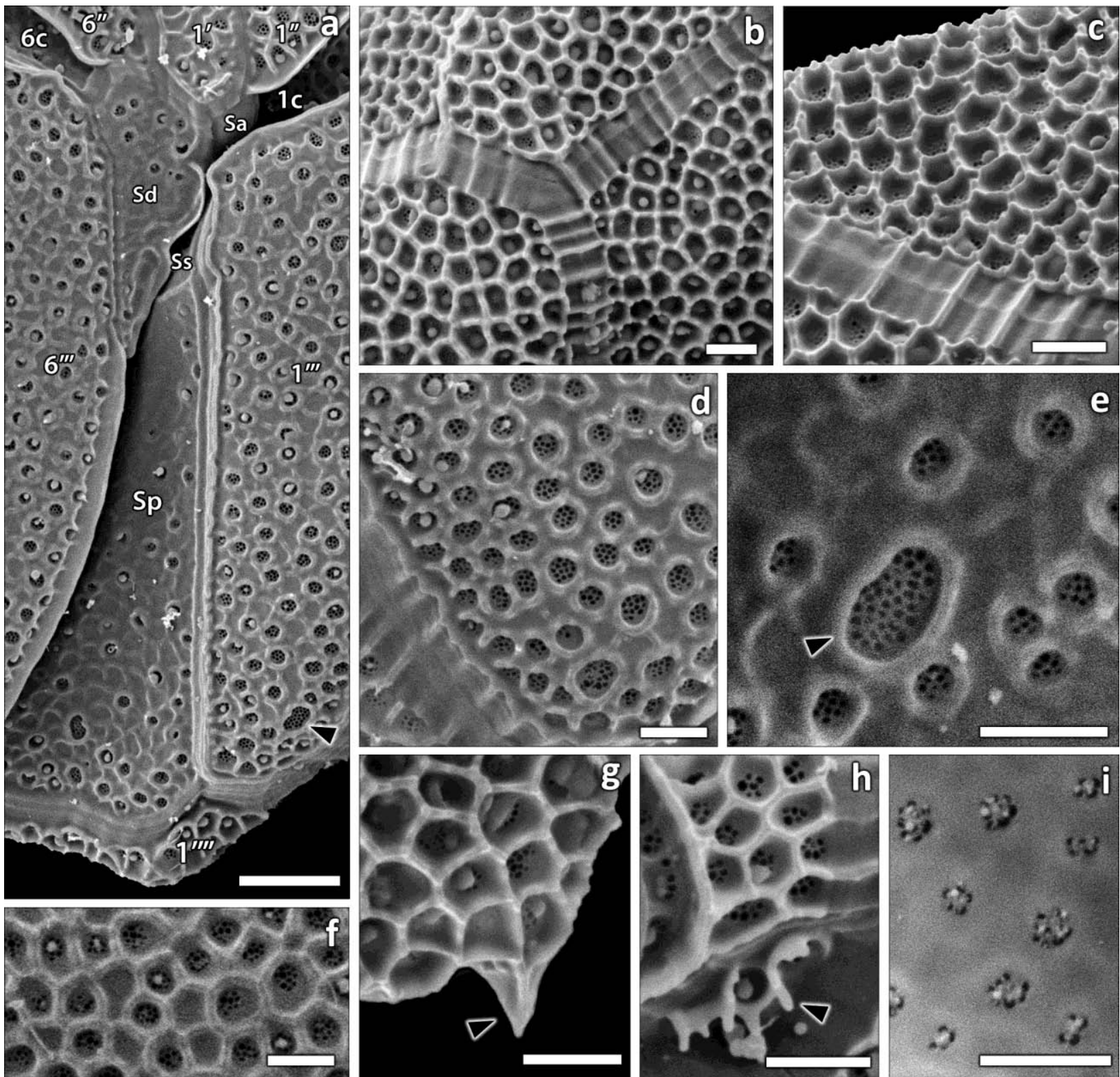

824

Fig. 5. Scanning electron micrographs of Ailadinium reticulatum gen. et sp. nov. (stub \# CEDiT2014H35). (a) Detail of the ventral side of the hypotheca showing the sulcus and surrounded plates. Arrowhead points the large marginal depression with sieve-like bottom. (b) Detail of the dorsal side of the hypotheca showing reticulate thecal surface and sutures. (c) Detail of the dorsal side of the hypotheca in oblique view showing the polygonal depressions with welldeveloped raised and crenulated sides and sutures. (d) Detail of the ventral side of the hypotheca showing the foveate thecal ornamentation consisting of round depressions with small pores at the bottom. (e) Detail of the ventral side of the hypotheca showing the large marginal depression with sieve-like bottom (arrowhead) and incomplete ridges between depressions. (f) Detail of the dorsal side of the hypotheca showing the polygonal depressions with numerous small pores at the bottom and depressions without pores. (g) Detail of the antapical part of the dorsal side of the hypotheca showing the asymmetrical spine (arrowhead). (h) Detail of the dorsal side of the epitheca showing the 2a plate with depressions surrounded by crest-like rims. (i) Inside view of the depressions of ventral cell side. Scale bars, $5 \mu \mathrm{m}$ in (a) and $2 \mu \mathrm{m}$ in (b-i). 

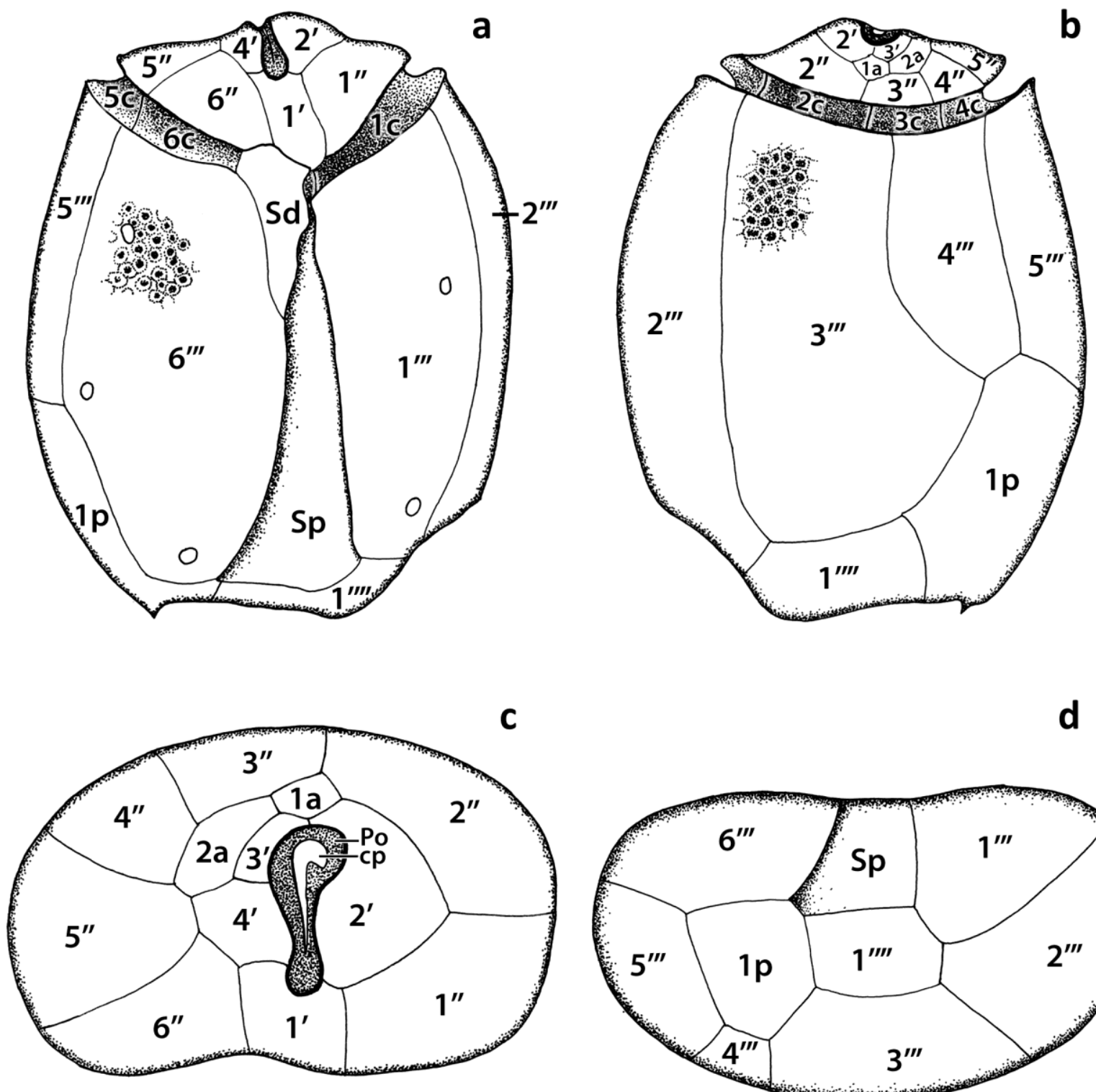

d

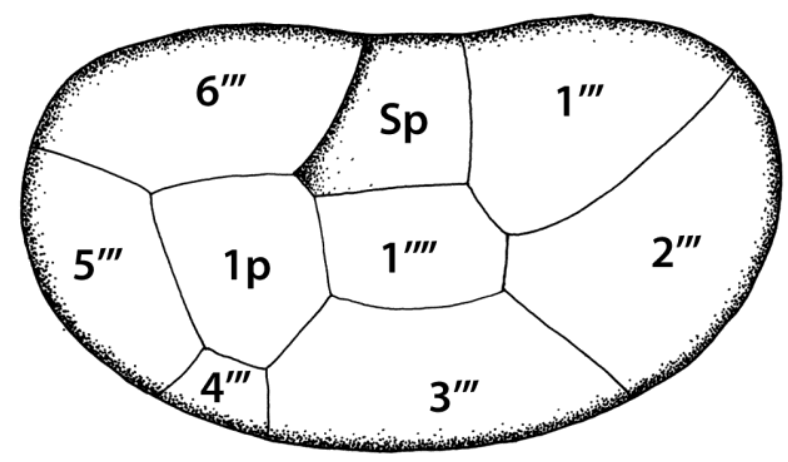

841 Fig. 6. Line drawings of Ailadinium reticulatum gen. et sp. nov. (a) Ventral view. (b) Dorsal view. (c) Apical view. (d) Antapical view. 


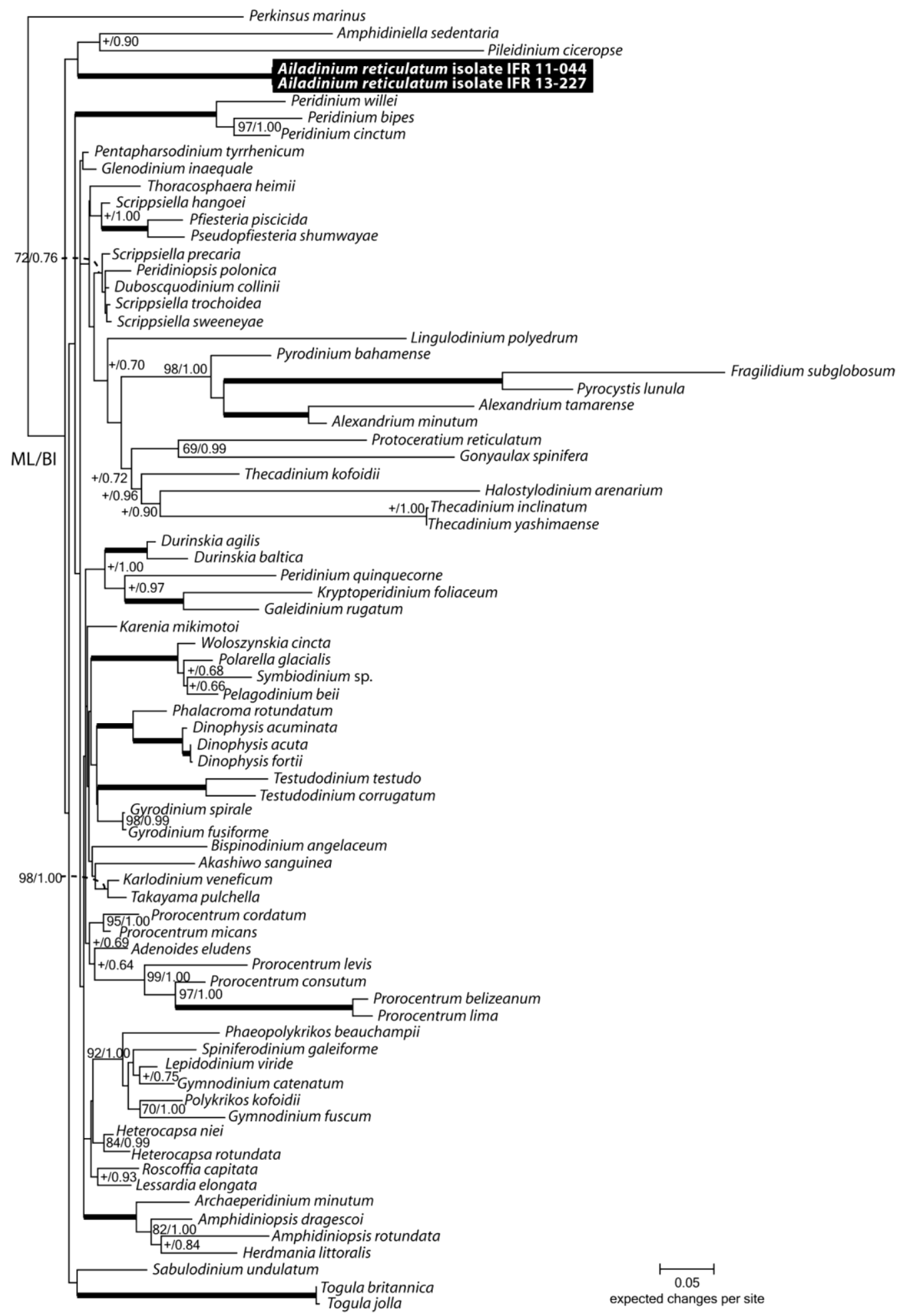

Fig. 7. Maximum likelihood (ML) phylogenetic tree inferred from SSU rDNA (matrix of 77 taxa and 1691 aligned positions). The tree was rooted using Perkinsus marinus sequence as outgroup. Model selected GTR $+\mathrm{I}+\Gamma_{4}$. Log likelihood $=-20365.9$. Substitution rate matrix: $\mathrm{A} \leftrightarrow \mathrm{C}=$ 1.554361, $\mathrm{A} \leftrightarrow \mathrm{G}=4.42400, \mathrm{~A} \leftrightarrow \mathrm{T}=1.43955, \mathrm{C} \leftrightarrow \mathrm{G}=0.81454, \mathrm{C} \leftrightarrow \mathrm{T}=9.29164$, against $\mathrm{G}$ $\leftrightarrow \mathrm{T}=1.00000$. Assumed nucleotide frequencies: $\mathrm{f}(\mathrm{A})=0.24586, \mathrm{f}(\mathrm{C})=0.19302, \mathrm{f}(\mathrm{G})=0.25297$, $f(T)=0.30815$. Among site rate variation: assumed proportion of invariable sites $I=0.324$. Rates at variable site assumed to be gamma distributed with shape parameter $\alpha=0.524$. Bootstrap values $(1,000$ pseudoreplicates) $>65$ (in ML) and posterior probabilities $>0.5$ (in BI) are shown at nodes, thick lines indicate full support of the branch (100/1.00). ' + ' indicate nodes present but 861 unsupported. 


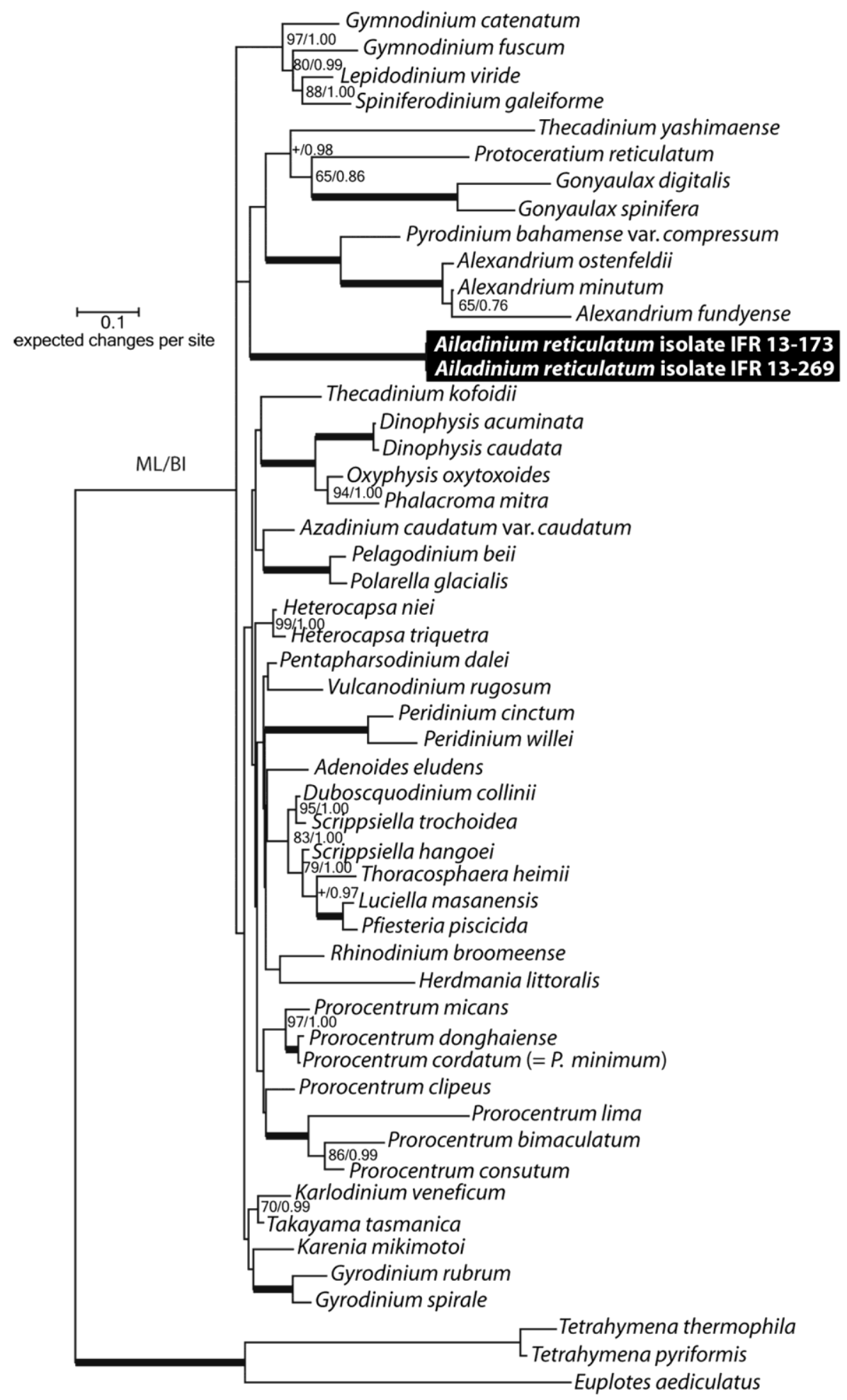

862 Fig. 8. Maximum likelihood (ML) phylogenetic tree inferred from partial LSU rDNA (matrix of 86352 taxa and 812 aligned positions). The tree was rooted using sequences of the Ciliates Euplotes 864 aediculatus, Tetrahymena pyriformis and Tetrahymena thermophila as external group. Model 865 selected GTR $+\Gamma_{5}$. Log likelihood $=-12325.47954$. Substitution rate matrix: $A \leftrightarrow C=0.78972$, $866 \mathrm{~A} \leftrightarrow \mathrm{G}=2.47397, \mathrm{~A} \leftrightarrow \mathrm{T}=0.93648, \mathrm{C} \leftrightarrow \mathrm{G}=0.64402, \mathrm{C} \leftrightarrow \mathrm{T}=6.36575$, against $\mathrm{G} \leftrightarrow \mathrm{T}=$ 867 1.00000. Assumed nucleotides frequencies $\mathrm{f}(\mathrm{A})=0.27083, \mathrm{f}(\mathrm{C})=0.19006, \mathrm{f}(\mathrm{G})=0.27936$, $868 \mathrm{f}(\mathrm{T})=0.25975$. Rates at variable site assumed to be gamma distributed with shape parameter $\alpha=$ 869 0.466. Only bootstrap values (1,000 pseudoreplicates) $>65$ (in ML) and posterior probabilities $>$ $870 \quad 0.5$ (in BI) are shown at nodes; thick lines indicate full support of the branch (100/1.00); ' + ' 871 indicates a node present but unsupported while absence of value indicate an unsupported branch 872 in ML and BI. 
874

875 APPENDIX S1: List of sequences used in phylogenetic analyses

876 GenBank accession numbers (in bold, sequences acquired in this study):

877

878 SSU rDNA sequences:

879 Adenoides eludens AF274249; Akashiwo sanguinea U41085; Alexandrium minutum JF521634; 880 Alexandrium tamarense AF022191; Amphidiniella sedentaria AB212091; Amphidiniopsis (as

881 Thecadinium) dragescoi AY238479; Amphidiniopsis rotundata AB639343; Archaeperidinium 882 minutum AB780999; Bispinodinium angelaceum AB762397; Dinophysis acuminata FJ869120;

883 Dinophysis acuta AJ506973; Dinophysis fortii AB073118; Duboscquodinium collinii

884 HM483399; Durinskia agilis JF514516; Durinskia baltica GU999528; Fragilidium subglobosum 885 AF033869; Galeidinium rugatum AB195668; Glenodinium inaequale EF058237; Gonyaulax 886 spinifera AF022155; Gymnodinium catenatum DQ779990; Gymnodinium fuscum AF022194;

887 Gyrodinium fusiforme AB120002; Gyrodinium spirale AB120001; Halostylodinium arenarium 888 AB036837; Herdmania littoralis AB564302; Heterocapsa niei EF492499; Heterocapsa 889 rotundata DQ388464; Karenia mikimotoi AF009131; Karlodinium veneficum EF492506; 890 Kryptoperidinium foliaceum EF492508; Lepidodinium viride DQ499645; Lessardia elongata 891 AF521100; Lingulodinium polyedrum AB693196; Pelagodinium beii JF791066;

892 Pentapharsodinium tyrrhenicum AF022201; Peridiniopsis polonica AY443017 ; Peridinium 893 bipes AF231805; Peridinium cinctum EF058243; Peridinium quinquecorne AB246744;

894 Peridinium willei EF058249; Perkinsus marinus AF126013; Pfiesteria piscicida DQ991382; 895 Phalacroma rotundatum AJ506975; Pheopolykrikos beauchampii DQ371294; Pileidinium 896 ciceropse AB211357; Polarella glacialis AF099183; Polykrikos kofoidii DQ371291; 897 Prorocentrum belizeanum DQ238042; Prorocentrum consutum FJ842379; Prorocentrum levis 898 DQ238043; Prorocentrum lima Y16235; Prorocentrum micans EU780638; Prorocentrum 
minimum JX402086; Protoceratium reticulatum DQ217789; Pseudopfiesteria shumwayae

900 AF080098; Pyrocystis lunula AF274274; Pyrodinium bahamense AF274275; Ailadinium

901 reticulatum isolate IFR 11-044 KJ187034; Ailadinium reticulatum isolate IFR 13-227

KJ187035; Roscoffia capitata AF521101; Sabulodinium undulatum DQ975474; Scippsiella sweeneyae HQ845331; Scrippsiella hangoei EF417316; Scrippsiella precaria DQ847435;

904 Scrippsiella trochoidea FR865630; Spiniferodinium galeiforme GU295203; Symbiodinium sp.

905 AB085911; Takayama xiamenensis AY800130; Testudodinium corrugatum AB704004;

906 Testudodinium testudo AB704002; Thecadinium inclinatum EF492515; Thecadinium kofoidii

907 AY238478; Thecadinium yashimaense AY238477; Thoracosphaera heimii HQ845327; Togula

908 britannica (as Amphidinium brittanicum) AY443010; Togula jolla (as Amphidinium

909 corpulentum) AF274252; Woloszynskia halophila EF058252.

910

911 LSU rDNA sequences:

912 Adenoides eludens FJ939580; Alexandrium fundyense FJ411147; Alexandrium minutum

913 JF521635; Alexandrium ostenfeldii EU707483; Azadinium caudatum var. caudatum JQ247702;

914 Dinophysis acuminata EF613351; Dinophysis caudata EU780644; Duboscquodinium collinii

915 HM483399; Euplotes aediculatus AF223571; Gonyaulax digitalis AY154963; Gonyaulax

916 spinifera AY154960; Gymnodinium catenatum JQ616825; Gymnodinium fuscum AF200676;

917 Gyrodinium rubrum AY571369; Gyrodinium spirale AY571371; Herdmania littoralis

918 AB564306; Heterocapsa niei JQ247713; Heterocapsa triquetra HQ902268; Karenia mikimotoi

919 EF469238; Karlodinium veneficum DQ114466; Lepidodinium viride DQ499645; Luciella

920 masanensis EU048553; Oxyphysis oxytoxoides EF613359; Pelagodinium beii DQ195370;

921 Pentapharsodinium dalei JX262498; Peridinium cinctum EF205011; Peridinium willei

922 EF205012; Pfiesteria piscicida FJ600087; Phalacroma mitra FJ808706; Polarella glacialis

923 JN558110; Prorocentrum bimaculatum HQ890883; Prorocentrum clipeus JX912175;

924 Prorocentrum consutum FJ842378; Prorocentrum cordatum EU780639; Prorocentrum 
925 donghaiense AY822610; Prorocentrum lima DQ336189; Prorocentrum micans X16108;

926 Protoceratium reticulatum AF260386; Pyrodinium bahamense var. compressum AY154959;

927 Ailadinium reticulatum isolate IFR 13-173 KJ187036; Ailadinium reticulatum isolate IFR

928 13-269 KJ187037; Rhinodinium broomeense DQ078782; Scrippsiella hangoei EF205016;

929 Scrippsiella trochoidea HQ670228; Spiniferodinium galeiforme GU295206; Takayama

930 tasmanica AY284948; Tetrahymena pyriformis X54004; Tetrahymena thermophila X54512;

931 Thecadinium kofoidii GU295207; Thecadinium yashimaense GU295209; Thoracosphaera heimii

932 EF205018; Vulcanodinium rugosum HQ622103.

933 